\title{
Torrent rainfall-induced large-scale karst limestone slope collapse at Khanh waterfall, Hoa Binh Province, Vietnam
}

\author{
Ngoc Ha Do ${ }^{1,4}$, Satoshi Goto $2^{*} \mathbb{0}$, Shinro Abe ${ }^{3}$, Kim Thanh Nguyen ${ }^{4}$, Toyohiko Miyagi ${ }^{5}$, Kazunori Hayashi ${ }^{3}$ and \\ Osamu Watanabe ${ }^{6}$
}

\begin{abstract}
In recent years, many landslides have occurred in Vietnam, particularly in the Northern mountainous region during the rainy season from May to October. On the morning of October 12, 2017, the Khanh waterfall landslide in Khanh Village, Hoa Binh Province, Northern Vietnam occurred. The landslide killed eighteen people and destroyed five houses. Topographical and geological surveys were conducted around the area to determine its causes. The rainfall data and flow discharge were also analyzed. The results showed that this collapse was different from some previous ones collapsed due to the erosion at the toe of the slope. Khanh waterfall landslide occurred due to the increasing amount of water in cracks and caves in the limestone layer in the slope. The collapse process was simulated based on Coulomb mixture theory. The numerical simulation results show similarities with the actual collapse process. The results provide indicators for assessing the risk of such limestone waterfall landslides in the future.
\end{abstract}

Keywords: Khanh waterfall landslide, Torrent rain, Limestone, Cave, Numerical simulation

\section{Introduction}

Vietnam has a humid monsoon climate with a high average annual rainfall. Damaging landslides occur every year during the rainy season. Studies on rainfall-triggered landslides in Vietnam such as in Binh Dinh Province (Duc 2013), Lao Cai Province (Bui et al. 2017), Quang Ninh Province (Loi et al. 2017; Nguyen et al. 2020), and Danang City (Quang et al. 2018) have identified the torrential rain as the primary cause of landslides in Viet Nam. Hoa Binh is the northern mountainous province most affected by landslides during the rainy season (Bui et al. 2013). On October 12, 2017, around 01:00 local time, a landslide occurred at Khanh waterfall, Phu Cuong Commune, Tan Lac District, Hoa Binh Province, Vietnam. The Khanh waterfall is located in a limestone area

\footnotetext{
${ }^{*}$ Correspondence: goto@yamanashi.ac.jp

${ }^{2}$ Faculty of Engineering, Graduate Faculty of Interdisciplinary Research,

University of Yamanashi, Yamanashi, Japan

Full list of author information is available at the end of the article
}

in Northern Vietnam (Fig. 1). In this study, we refer to this landslide as the local name, Khanh waterfall landslide. This used to be a tourist destination with a beautiful scenery of the waterfall.

The landslide caused a great damage killing 18 people and destroying 5 households on the opposite hill of the Khanh waterfall. Before this disaster, Khanh Village residents witnessed minor size slope collapses earlier in the rainy season in September. However, no significant landslides have previously been recorded at the Khanh waterfall. As a result, landslide risk early warning and evacuations were not contemplated before the disaster. The sudden landslide moved a large amount of rock and soil downhill, across the river, and up the opposite hill for a total moving distance of about $400 \mathrm{~m}$.

There are many tourist destinations that feature beautiful and famous waterfalls in the world. Another wellknown waterfall in the limestone belts in Vietnam is Ban Gioc waterfall located in Cao Bang province, Northern Vietnam. In other countries, there are many scenic spots 

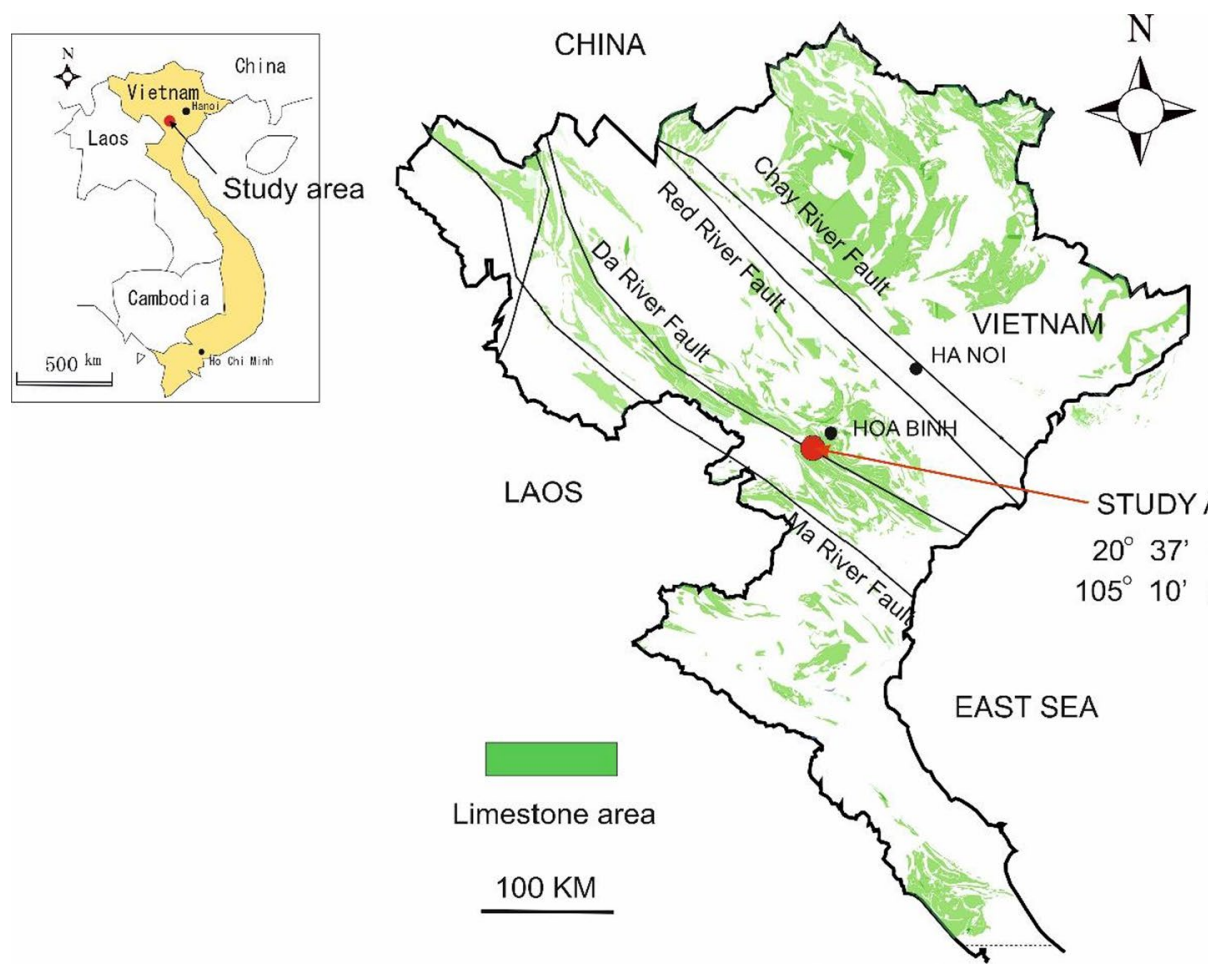

DY AREA

$20^{\circ} 37^{\prime} 44.56^{\prime \prime} \mathrm{N}$

$105^{\circ} 10^{\prime} 36.88^{\prime \prime} \mathrm{E}$

in karst terrain such as Tamul Falls in Mexico and Plitvice Lakes Falls in Croatia. However, until now little is known about landslides that cause a great loss of life at limestone waterfalls known as scenic spots. Hence, it is very important to understand the mechanism of the landslide occurred at the Khanh waterfall.

Several previous studies on the collapse of waterfalls focused on the transition process of rivers (Scheingross and Lamb 2017). However, there were only a few studies on the collapse of waterfalls as disasters such as Kegon waterfall in Nikko, Japan (Hayakawa 2013), Niagara waterfall between America and Canada (Hayakawa and Matsukura 2010). This study is focused on the clarifying of the mechanism of the Khanh waterfall landslide. Such factors as topographical and geological background, rainfall and groundwater are analyzed. The water quality and the flow simulation of the moving soil and water masses were also analyzed. Finally, as the expansion of cave in limestone areas in Vietnam is still developing (Khang 1985), assessing the possibility of recurrence of similar landslides would be very meaningful.

\section{Study area}

\section{General geology}

The study area is located at the Song Ma suture zone (Hau et al. 2018) due to the collision of the South China craton and Indochina craton during the late Paleozoic to early Mesozoic period. The limestones are distributed along the northwest-southeast tectonic line (Da River fault) (Fig. 1). In recent years, many landslides due to heavy rainfall have occurred in the margin of this limestone zone (Tung et al. 2016). The main geology of the study area consists of shale and limestone from the Triassic of Mesozoic (Fig. 2).

Khanh waterfall is located on the right bank of the Kem river that flows under the cliff. Behind it, steep terrain with unevenness peculiar to the limestone area at an altitude of $350 \mathrm{~m}$ to $1000 \mathrm{~m}$ spreads from northwest to southeast. On the other hand, the left bank of the River Cam, where shale is mainly distributed, is a relatively flat terrain with an altitude of $200 \mathrm{~m}$ to $250 \mathrm{~m}$, and villages are formed along the national highway.

Shale is distributed on the left bank of the Kem river, and limestone with shale on the right bank. The stratigraphy is $N 40-50^{\circ} \mathrm{W}$, the dip is $70^{\circ}-80^{\circ} \mathrm{W}$. There is a small fault on the slope of the Khanh waterfall that dips about $45^{\circ} \mathrm{E}$ as shown in Fig. 18 later. The Kem river itself, which flows in the direction of the strike of stratum, may also correspond to a fault.

Geotechnical investigation including the strength and permeability of each layer was not conducted in detail in this study. However, preliminary testing of the strength 


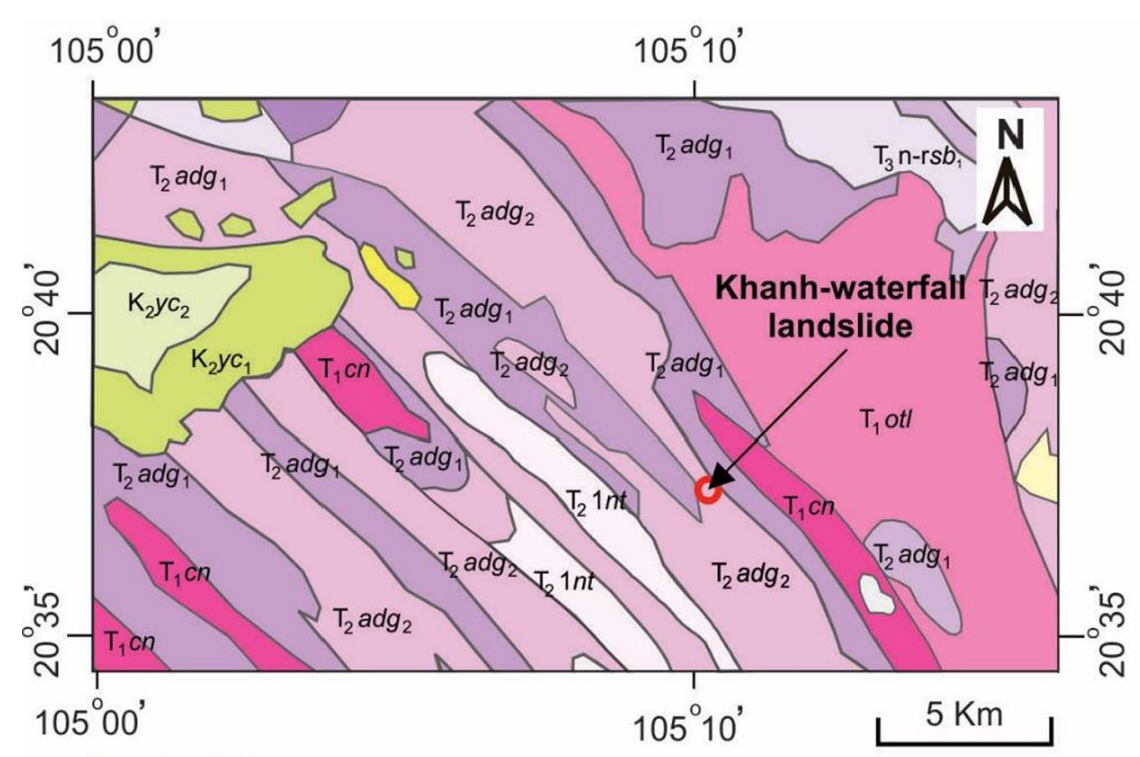

$\mathrm{T}_{2} \mathrm{adg}_{2}$ Dong Giao Upper Subformation: ligh-coloured massive limestone marl.

$\mathrm{T}_{2} \mathrm{adg}_{1}$ Dong Giao Lower Subformation: thin-beadded black-grey limestone, some interbeds of cherty limestone.

$\mathrm{T}_{1} \mathrm{cn}$

Co Noi Formation: sandstone, tuffaceous siltstone, clay shale, marl, nodular clayey limestone.

$\mathrm{T}_{1}$ otl Tan Lac Formation: sandstone, tuffaceous sandstone, lenses of conglomerate, siltstone, tuffite, clay shale, clayey limestone.

$\mathrm{T}_{2} 1 \mathrm{nt}$ Nam Tham Formation: calcareous siltstone, marlaceous shale, clay shale, interbeds of fine-medium grained sandstone.
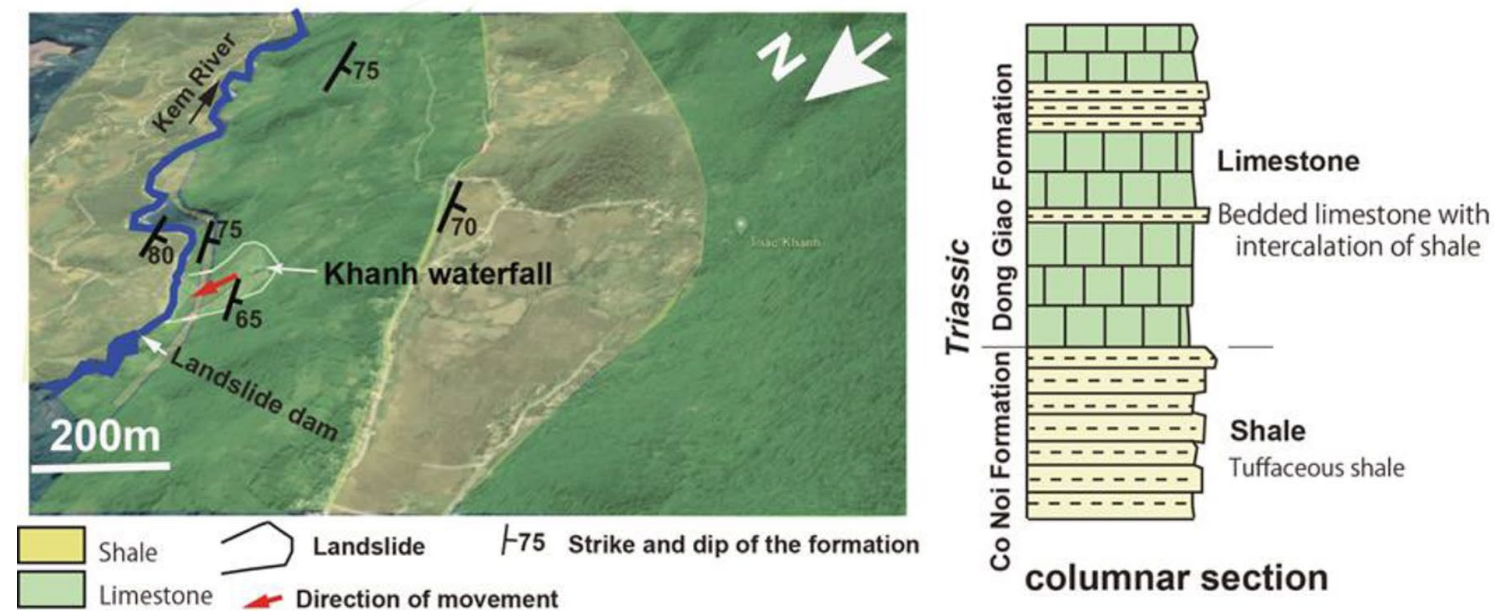

Fig. 2 Geological map and schematic geological columns around Khanh waterfall (Modified from Department of Geology and Minerals of Vietnam 2004, 2005)

of the rock with a hammer was carried out. Both shale and limestone have a stratified structure. These rocks are soft with weathering at the surface of the outcrop. But the fresh part is hard that it cannot be easily broken by hammering. Based on the study on limestone at a similar age (Konecny et al. 2017), the unconfined compressive strength of the limestone layer is $69-204 \mathrm{MPa}$.

The river is littered with limestone boulders as landslide moving masses as well as stalactite rubble rich in cavities. They were probably formed by groundwater 
in cracks and cavities in the limestone. It is considered that the permeability of such shale and limestone itself is low. However, the slope of these strata forming a layered structure is almost vertical from $70^{\circ}$ to $80^{\circ}$. Moreover, there were many cracks and cavities in the limestone layer. Hence, surface water easily penetrated into cracks and cavities in the limestone layer.

\section{Features of the slope failure}

The Khanh waterfall landslide occurred around 01:00 am local time on October 12, 2017 after $48 \mathrm{~h}$ of a heavy rainfall of $394.8 \mathrm{~mm}$ on October 10 and 11, 2017 (Fig. 3). The rainfall data was collected at Mai Chau district rain gauge station, which is located $12 \mathrm{~km}$ from Khanh waterfall (Vietnam Meteorological and Hydrological Administration 2019). At the Khanh waterfall, there were two branches of the fall named Khanh waterfall 1 and Khanh waterfall 2 (Fig. 4).

When the landslide occurred, only Khanh waterfall 1 collapsed. Khanh waterfall 2 did not collapse. According to the survey of the upper stream network of Khanh waterfall, waterfall 1 and waterfall 2 have the same water source. However, the main stream flows towards waterfall 1 , the secondary stream flows towards waterfall 2 . Therefore, when the heavy rain occurred, more water was directed to the waterfall 1 area due to its geological characteristics that resulted in the slope collapse. The original dimensions of the Khanh waterfall 1 were a height of approximately $120 \mathrm{~m}$, a maximum thickness of $50 \mathrm{~m}$, and a width of $200 \mathrm{~m}$. A part of the landslide mass deposited at the Kem River forming a natural dam. Other parts of the mass crossed the Kem

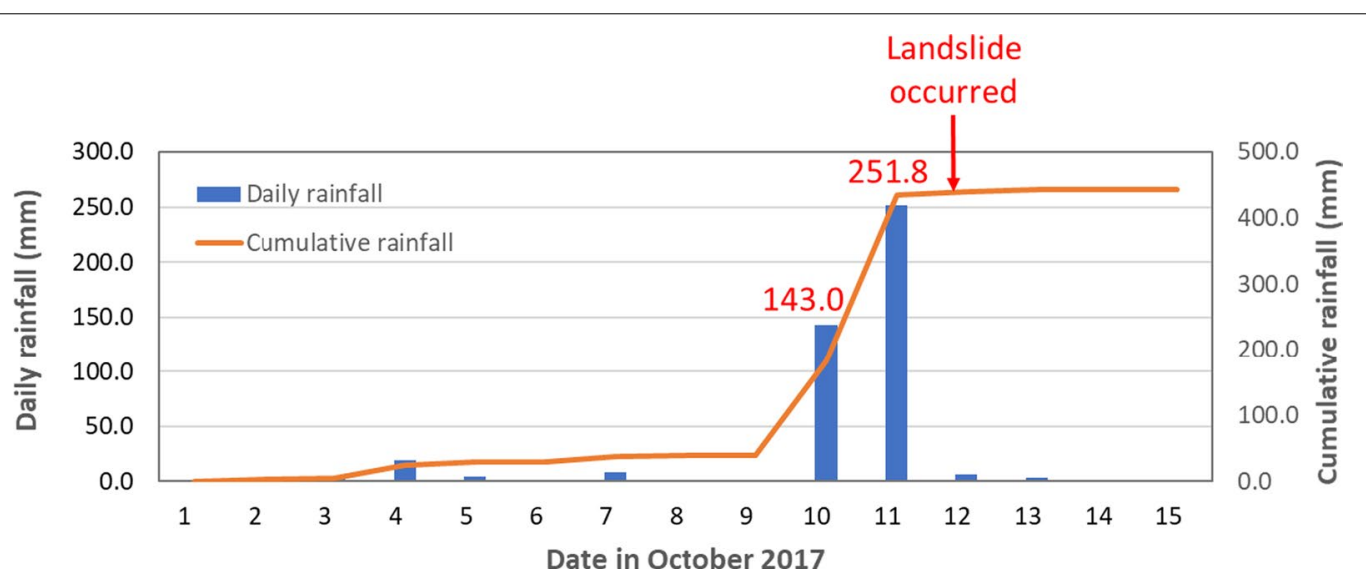

Fig. 3 Daily rainfall in October 2017 when the Khanh waterfall landslide occurred (Vietnam Meteorological and Hydrological Administration 2019)

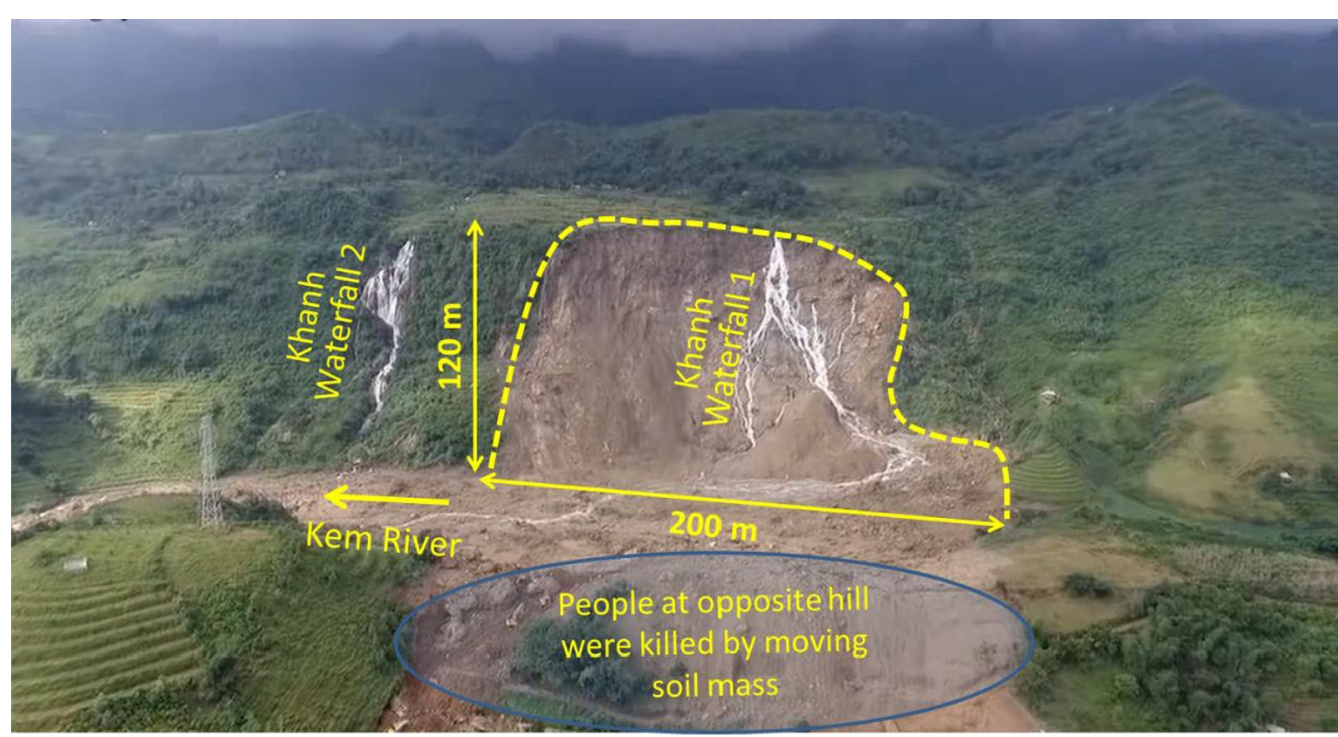

Fig. 4 The overview of Khanh waterfall landslide (Photo taken by Tuoi Tre Media 2017) 
River, passed over the top of the $30 \mathrm{~m}$ high hill on the opposite riverbank, and reached the paddy field. The deposit part at opposite hill killed 18 people living there (Fig. 5).
Figure 6 shows photos of the Khanh waterfall landslide taken at different times before and after the collapse of the waterfall. It shows the increase in the water around the waterfall during a heavy rain in 2017. The slope in

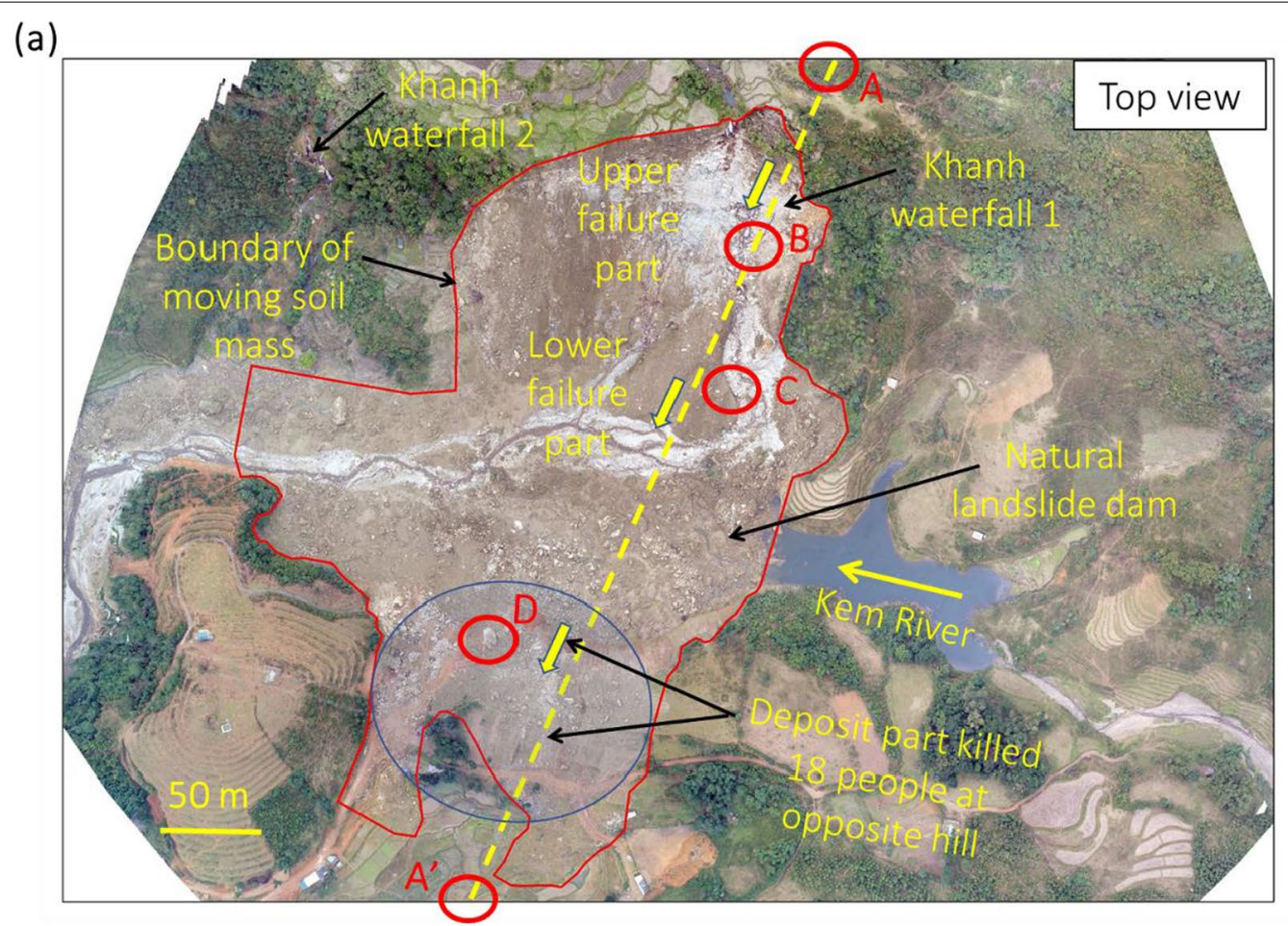

$A, B, C, D, A^{\prime}$ Photos position

(b)

Khanh Khanh waterfall 2 waterfall 1
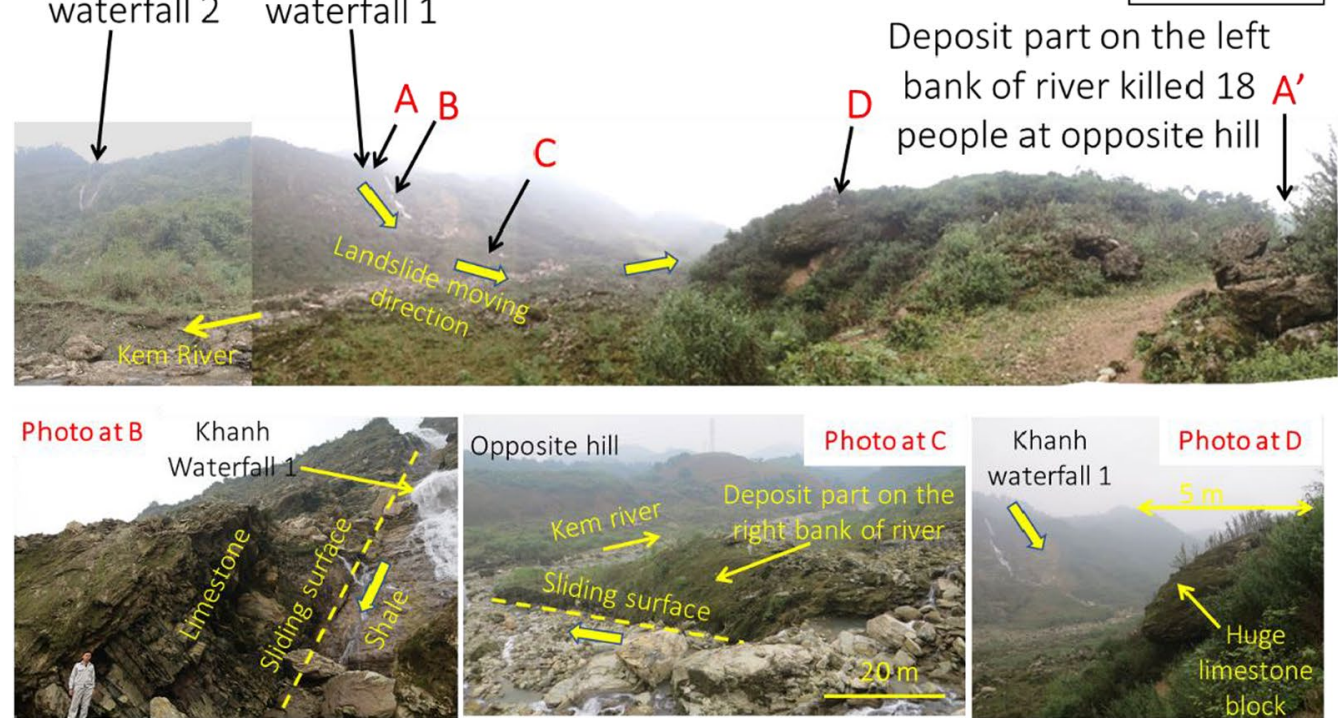

Fig. 5 Photos of Khanh waterfall along the line A-A' of the landslide moving direction: $\mathbf{a}$ top view, $\mathbf{b}$ side view 

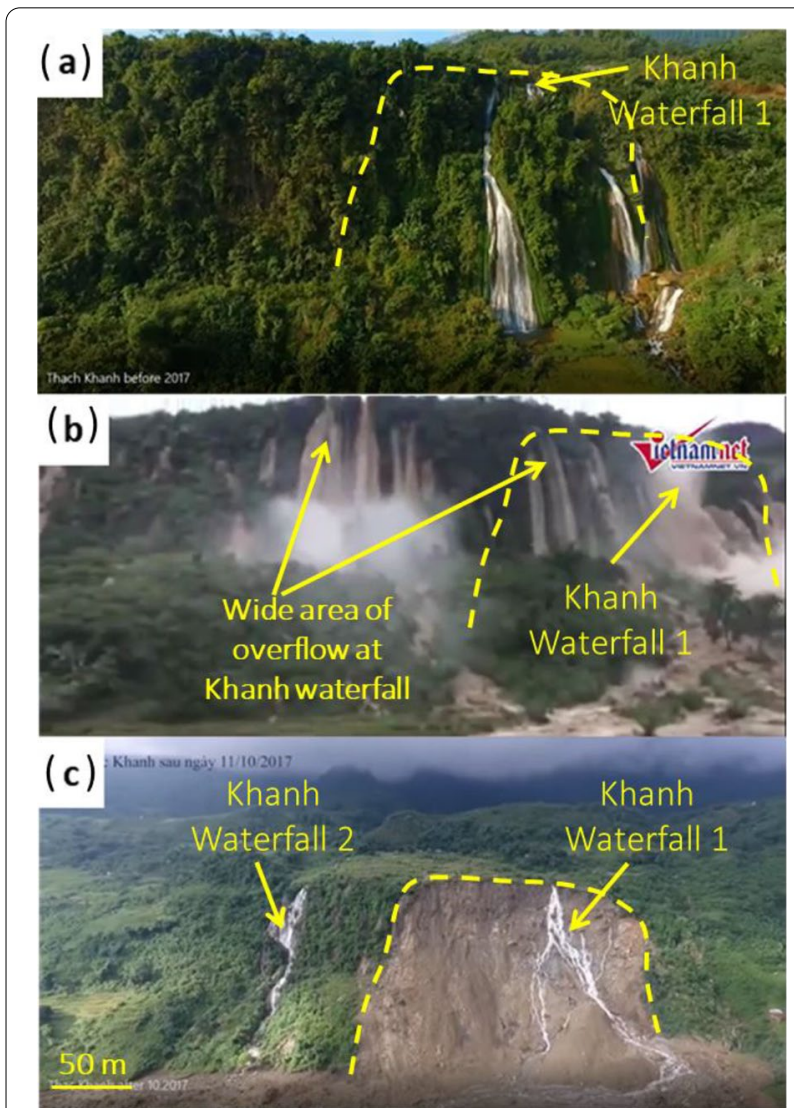

Fig. 6 Front view photos of Khanh waterfall: $\mathbf{a}$ in dry season before failure, $\mathbf{b}$ in rainy season 2017 reportedly days before the landslide occurred, c after the landslide occurred in 2017 (Photo taken by Tuoi Tre Media 2017; Vietnamnet 2017)

the dry season before 2017 was introduced as a beautiful waterfall destination for tourism (Fig. 6a). Figure 6b shows the situation of the slope in the rainy season of 2017, days before the landslide occurred. A large amount of brown water flowing from the entire slope included the waterfall as well as water ejected from the middle of the slope. Figure $6 \mathrm{c}$ shows the landscape after the slope area around the waterfall mostly collapsed. The moving mass containing boulders reached the opposite hill on the left bank of the river.

\section{Methodology}

To study the mechanism of the Khanh waterfall landslide, field surveys in the area surrounding it were conducted. Rainfall data around this area was also collected for the study. To evaluate the drainage capacity upstream of the waterfall, a measurement of the upstream network channel was conducted. The surface water and spring water were collected to analyze the water source relationship between the collapse area and the neighboring area. Topography, geology, rainfall, drainage capacity are considered as the factors contributing to the landslide. Moreover, a numerical model was created to simulate the landslide process. The affected area from the simulation results was compared with the one determined from the actual image.

\section{Field study}

Field surveys were conducted to understand the geology, topography and hydrogeology around Khanh waterfall landslide (Fig. 7). The range of movement and the amount of moving mass were estimated based on the actual geological evidence, information provided by the local residents, and the images taken by an Unmanned Aerial Vehicle (UAV).

Figure 8 shows the topographic classification map and the distribution map of the landslides in the Khanh waterfall area. The soil layers between the collapsed and the non-collapsed areas were investigated to determine the position of the collapsed surface. On the right bank of Kem river $200 \mathrm{~m}$ downstream from Khanh waterfall landslide, there were two areas P1 and P2 which were parallel concave terrains similar to the traces of past landslides. There was no movement at these points when the landslide occurred at Khanh waterfall. Water quality analysis and geology investigation at P1 and P2 areas were conducted to compare these condition with Khanh waterfall.

One water sample No. 012 (surface water) was collected from Khanh waterfall 1 . Two water samples No. 010 (surface water), 011 (spring water) were collected from Khanh waterfall 2. Two samples No. 005 and 008 (spring water) were collected from areas P1 and P2. In order to investigate the water quality characteristics, samples of spring water and swamp water around the landslide area were collected to analyze in the laboratory. Such parameters as the water temperature $(\mathrm{T}), \mathrm{pH}$, and electrical conductivity (EC) were measured in the field.

\section{Rainfall and flow discharge calculation}

Figure 9 shows the position of Khanh waterfall landslide in 2017 and areas in close proximity where landslides occurred previously (Tan et al. 2015) plotted on Google Earth, and a rainfall data graph from 1961 to 2018. In Fig. 9a, the location of Khanh waterfall, Mai Chau rainfall station and the previous nearby landslides areas in Pu Bin commune and Thung Khe commune, Mai Chau district, Hoa Binh province are shown. There were two landslides in 1996 and 2007 in Pu Bin commune and one landslide in Thung Khe commune in 2005. The exact locations, sizes and types of these landslides were not specified. However, the time when the landslides occurred has been reported. Figure $9 \mathrm{~b}$ shows the maximum $24 \mathrm{~h}, 48 \mathrm{~h}$ rainfall data at Mai Chau rainfall station from 1961 to 2018 with the time when Khanh waterfall landslide and 


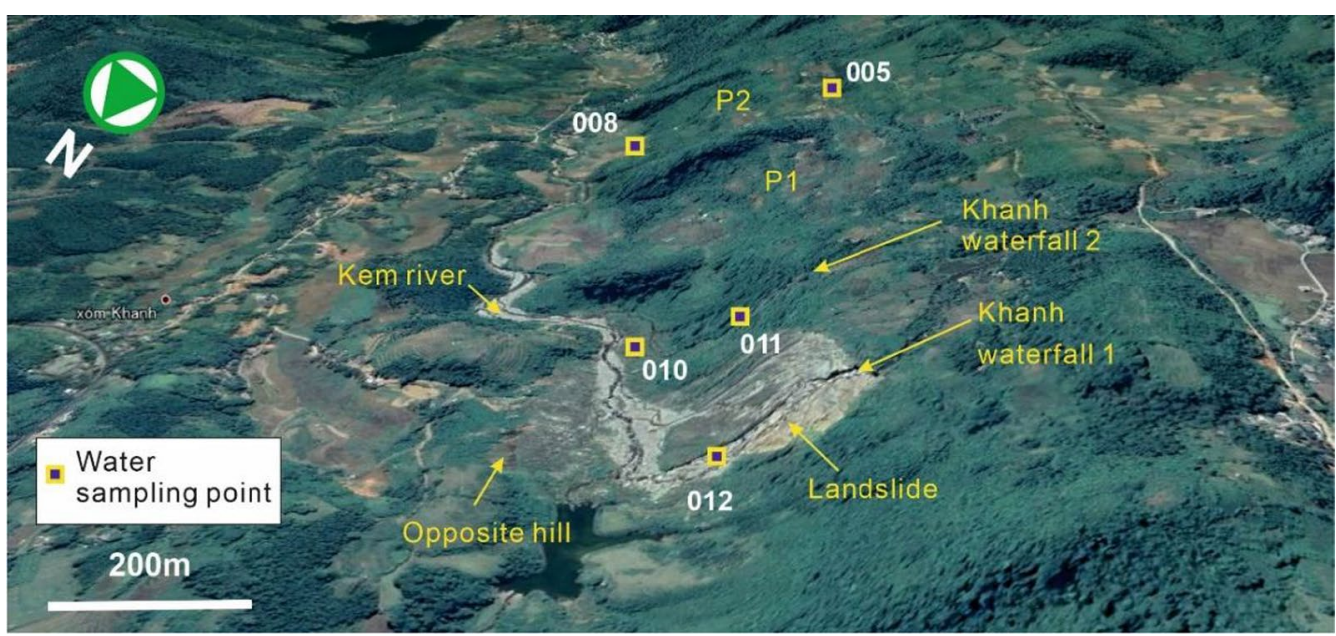

Fig. 7 Field survey area including the location of water sampling points around Khanh waterfall (KW) landslide. Sample 012 (surface water) was collected from KW1. Samples 010 (surface water), 011 (spring water) were collected from KW2. Samples No. 005 and 008 (spring water) were collected from P1 and P2 areas

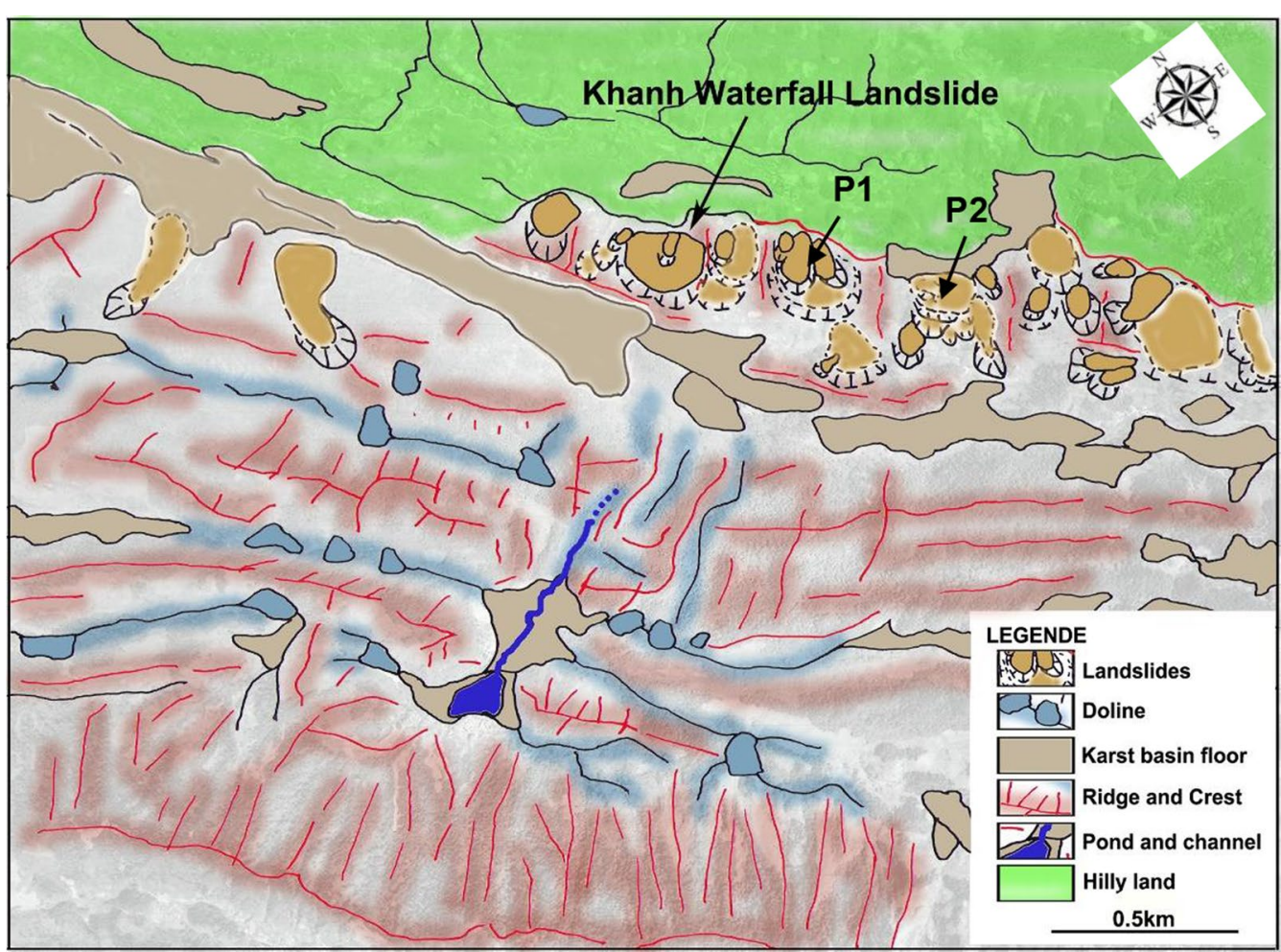

Fig. 8 Topographic classification and landslide distribution map around Khanh waterfall

previous nearby landslides occurred. It shows that the $48 \mathrm{~h}$ rainfall higher than $300 \mathrm{~mm}$ caused landslides that occurred in Pu Bin commune in 1996, 2007 and Khanh waterfall landslide in 2017 . The $24 \mathrm{~h}$ rainfall higher than $200 \mathrm{~mm}$ caused a landslide in Thung Khe commune in
2005. The data of the previous landslides and the current one at Khanh waterfall in the context of the rainfall data for 58 years indicates that torrent rainfall in $24 \mathrm{~h}$ and $48 \mathrm{~h}$ is an important factor causing landslides around Khanh 


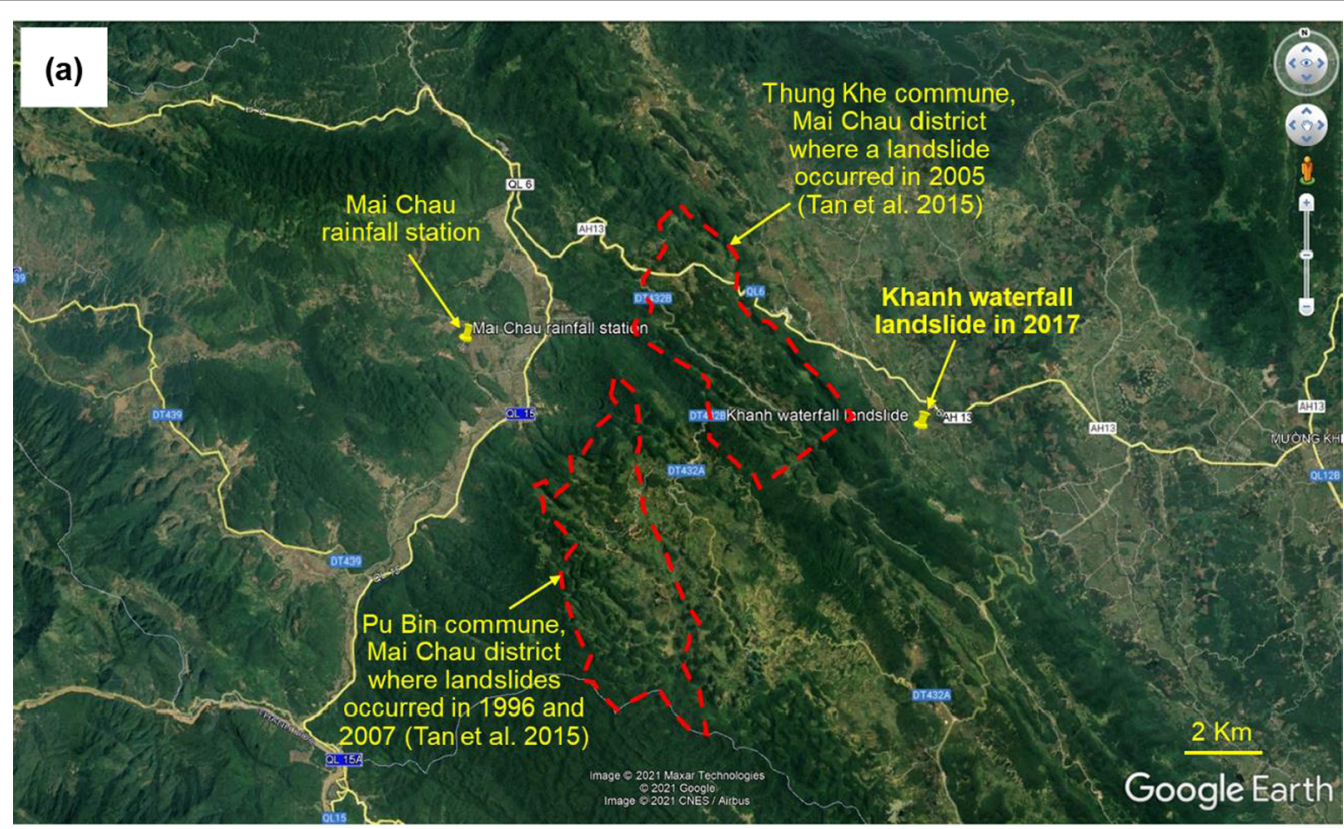

(b)

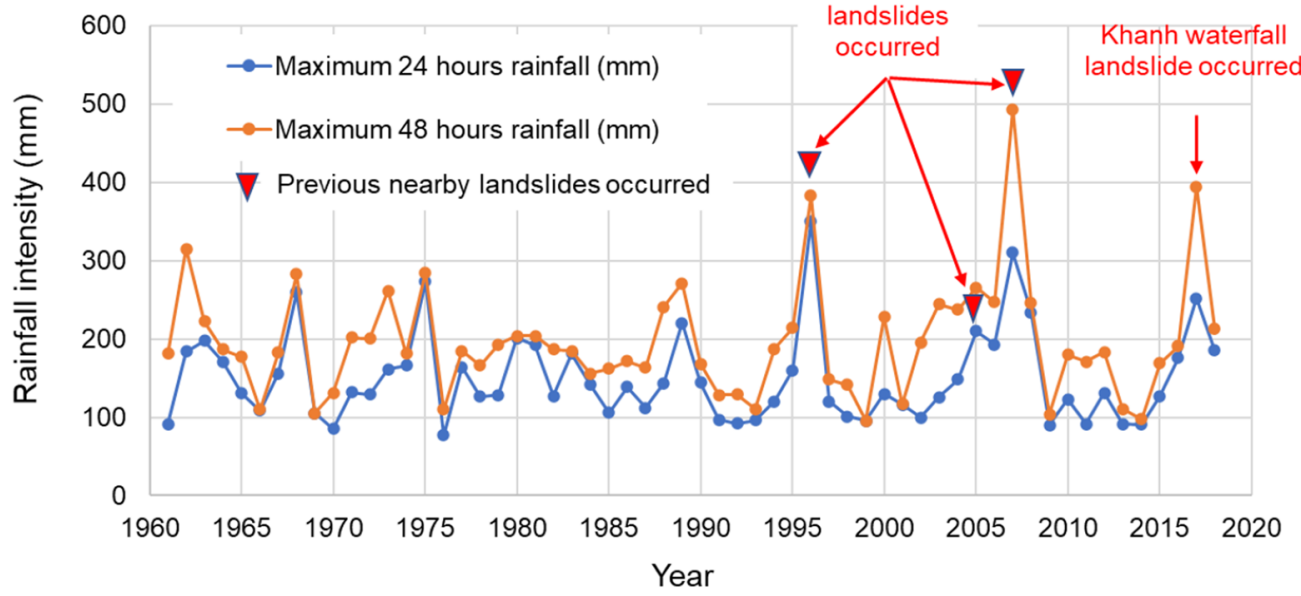

Fig. 9 a Location of Khanh waterfall (2017) and previous nearby landslides in Pu Bin commune and Thung Khe commune, Mai Chau district, Hoa Binh province (Tan et al. 2015); b data of maximum $24 \mathrm{~h}$ and $48 \mathrm{~h}$ rainfalls from 1961 to 2018 (Vietnam Meteorological and Hydrological Administration 2019)

waterfall. Rainfall in $48 \mathrm{~h}$ greater than $300 \mathrm{~mm}$ should be considered a warning landslides around this area.

In 2017, when the landslide occurred, there were large typhoons in October in Vietnam. The monthly rainfall in October of $448.8 \mathrm{~mm}$ was 2.6 times the usual amount of 170.4 mm (Fig. 10). On October 10 and 11, 2017, $48 \mathrm{~h}$ before the landslide occurred, the rainfall was recorded at $394.8 \mathrm{~mm}$. A maximum of $44.1 \mathrm{~mm} / \mathrm{h}$ was recorded at 4 am on October 11 (Fig. 11). This hourly rainfall value was used to calculate the flow discharge in the upstream area of Khanh waterfall. The watershed behind the landslide area was $21.17 \mathrm{~km}^{2}$. The water was gathered behind the Khanh waterfall and flowing down to the Khanh waterfall (Fig. 12).

The flood discharge that flowed down to the Khanh waterfall during heavy rainfall when the landslide occurred was calculated using the following Rational Method (Hicks et al. 2009). This is a common method used to calculate flow discharge for rivers in mountainous areas where the watershed area is less than $100 \mathrm{~km}^{2}$ and there are no adjustment facilities along the river. 


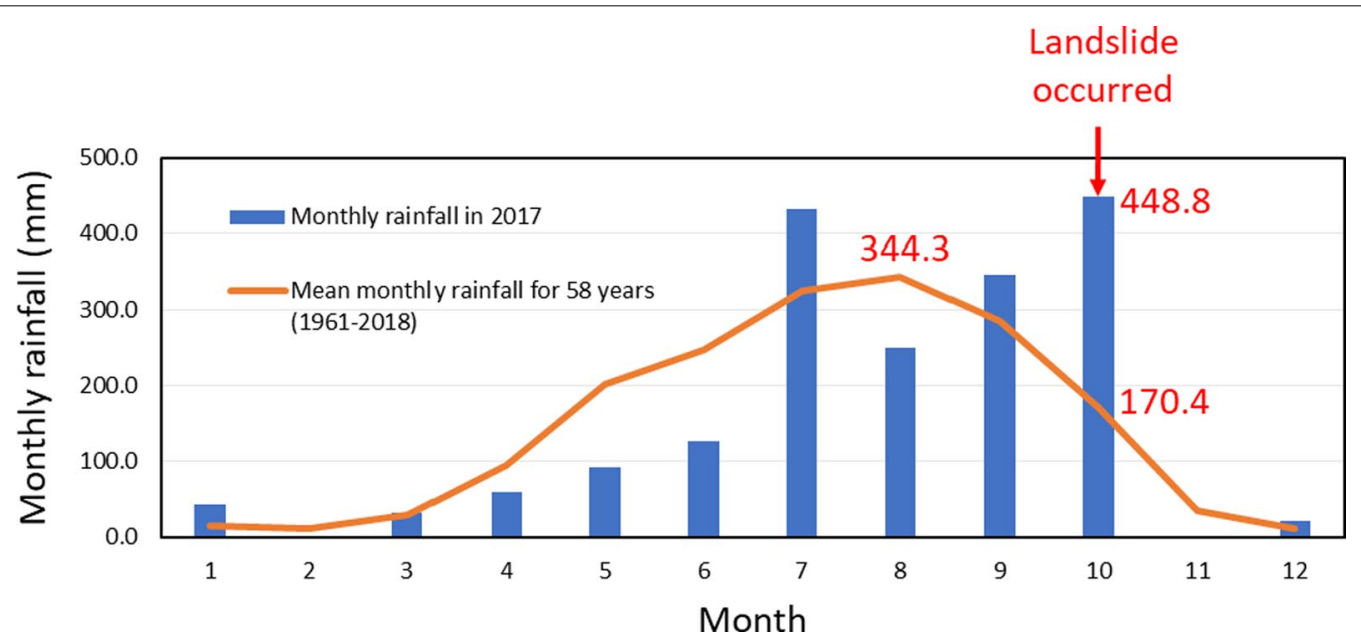

Fig. 10 Comparison of an average monthly precipitation and 2017 monthly precipitation in 1961-2018 (Vietnam Meteorological and Hydrological Administration 2019)

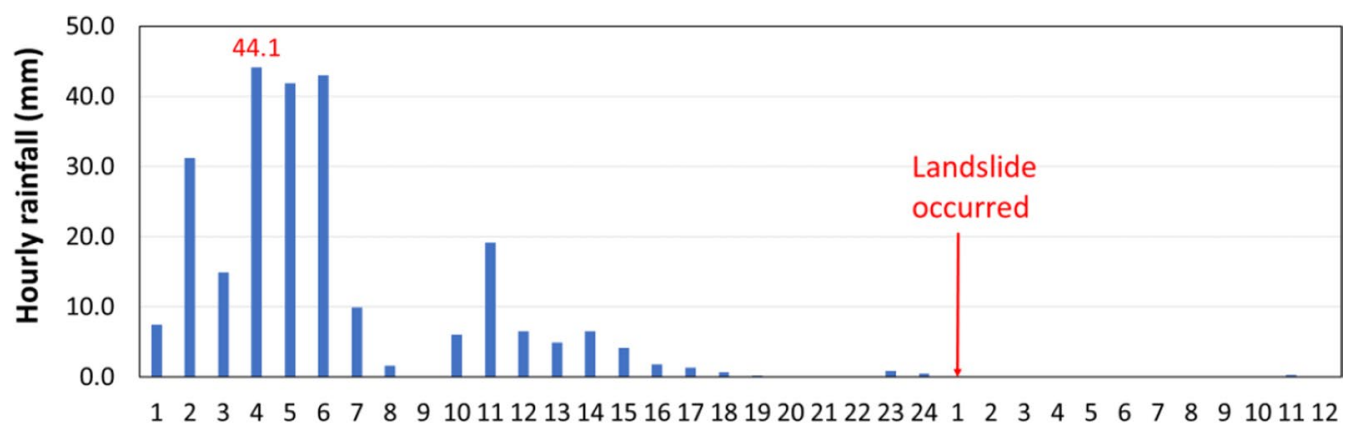

Hourly on October 11 and October 12, 2017

Fig. 11 Hourly rainfall on October 11 and October 12, 2017 when the Khanh waterfall landslide occurred (Vietnam Meteorological and Hydrological Administration 2019)

$$
Q=\frac{1}{3.6} \cdot f \cdot r \cdot A
$$

where $Q$ is peak flow $\left(\mathrm{m}^{3} / \mathrm{s}\right), f$ is discharge coefficient, $r$ is rainfall intensity $(\mathrm{mm} / \mathrm{h})$, and $A$ is watershed $\left(\mathrm{km}^{2}\right)$.

\section{Slope stability analysis and numerical simulation of collapse process}

To explain slope instability, the method from Hoek and Bray (1974) is used. A simply modified theoretical models of plane slope failures in Khanh waterfall is drawn in Fig. 13. It is assumed that there are many cracks and caves in the limestone layer in Khanh waterfall slope. The water in cracks and caves is from the upper stream network channel of Khanh waterfall. The factor of safety against the sliding block was calculated as follows:

$$
F S=\frac{c^{\prime} l+\left(W_{b} \cos \theta-U-V \sin \theta\right) \tan \phi^{\prime}}{W \sin \theta+V \cos \theta}
$$

where $F S$ is factor of safety, $c$ is the effective cohesion of sliding joint, $l$ is length of the sliding joint, $W_{b}$ is the weight of sliding block, $U$ is the uplift water pressure, $V$ is the horizontal water pressure, $\theta$ is the angle of the sliding surface, $\phi^{\prime}$ is the effective friction angle of the sliding joint.

It is assumed that when heavy rain, the surface water flowed into the void in the cracks and cavities in the limestone layer. This amount of water increased the water pressure that destroys the slope. The specific calculation of the factor of safety was not considered in this study. However, to simulate the slope collapse due to a large amount of water in the limestone layer corresponding to the peak flow discharge, the simulation 


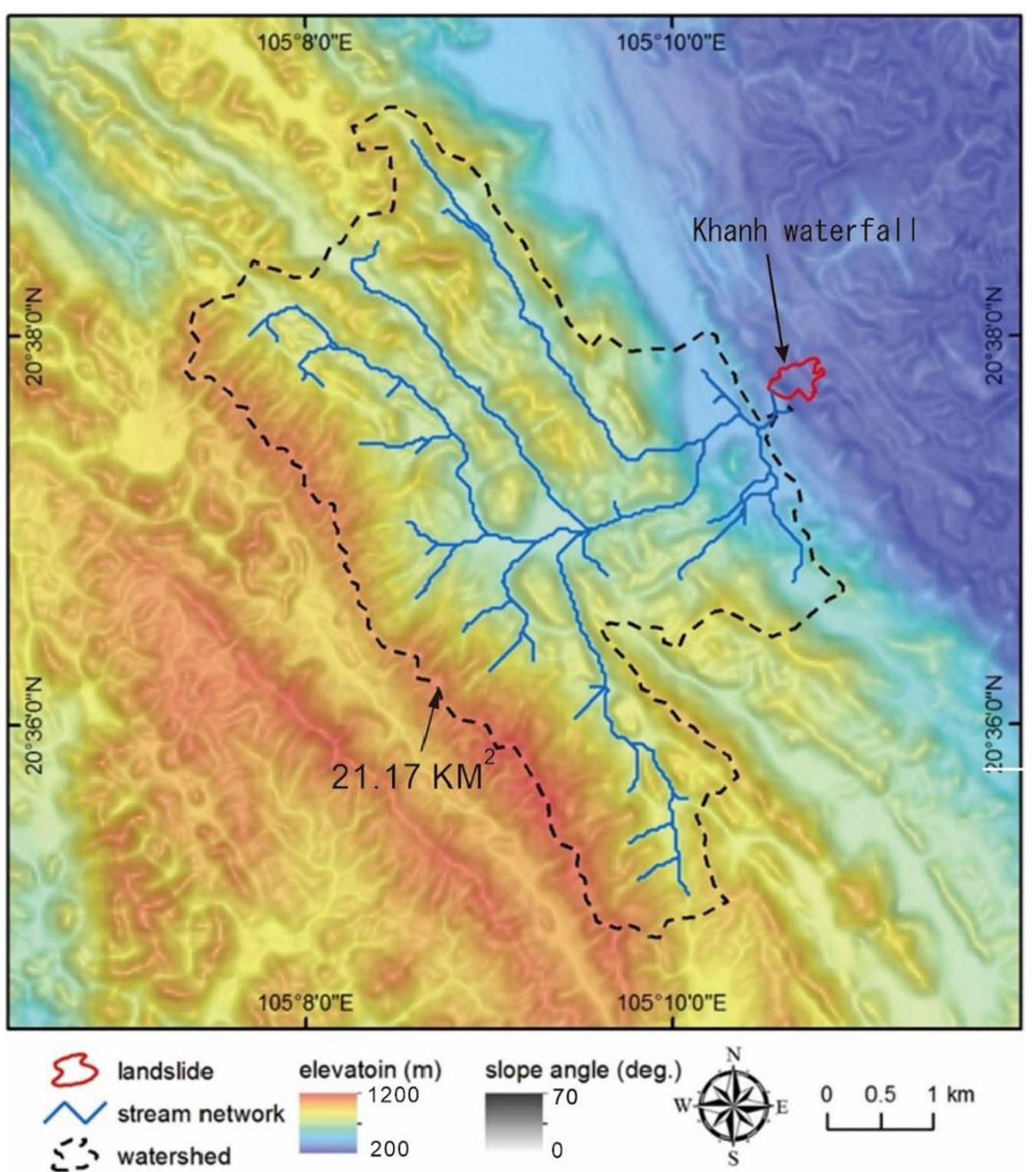

Fig. 12 The upper stream network channel and watershed of Khanh waterfall landslide

method to predict the behavior of grain-fluid flows due to slope collapse (Zhang et al. 2004) is applied in this study. This method assumes that grain-fluid flows behave as mixtures of interaction of Newtonian fluids and Coulomb solids. The equations that describe the mixtures based on Coulomb mixture theory (Denlinger and Iverson 2001). In order to exactly predict the range of sediment, the momentum equation was discretized by the finite difference method with applied a stop condition of grain-fluid flow, the third-order upwind scheme, and the preserving mass conservation method to the numerical model (Zhang et al. 2004).
Figure 14 shows the relationship between the slope angle of the source area $(\theta)$, runout distance $(L)$, and runout height $(H)$ (Moriwaki 1987). The coefficient of friction is close to the the tangent of the slope angle (Scheidegger 1973). It is considered that the slope angle before and after collapse explains the internal friction angle and basal friction angle.

Table 1 shows the physical properties of the flow simulation. It is assumed that the resistance force on the failure surface during the flow depends only on the friction at the contact surface between the landslide mass and 
the basal rock. The tangent of the ratio between runout height $(\mathrm{H})$ and runout distance $(\mathrm{L})$ after collapse is equal to the basal friction angle. The tangent of the ratio of height of source slope $\left(\mathrm{H}^{\prime}\right)$ and the length of source slope (L') before collapse is equal to the internal friction angle. In the case of Khanh waterfall, the internal friction angle $\left(\phi_{\text {int }}\right)$ and the basal friction angle $\left(\phi_{\text {bed }}\right)$ of grain-fluid flows were 30 degrees from $\tan \theta=0.55$ and 15 degrees from $H / L \fallingdotseq 0.23$ based on the geometric shape of slope before and after collapse (Table 2).

Table 3 shows the calculation of the ratio of basal pore fluid pressure. The density of solid was referred from Konecny et al. (2017). Based on the field survey, the ratio of solid and void was determined as 0.6 and 0.4 , respectively. The ratio of water and air in the void represents the different cases of pore water pressure. Since it was torrent rainfall at the time of the slope collapse, the ratio of water and air was determined as 0.4 and 0 , respectively. Simulations of cases where the water ratio is less than 0.4 are also calculated. However, the simulation results of these cases differ from the real landslide aftermath. As a result, the ratio of basal pore fluid pressure $(\lambda)$ was set to 0.5 corresponding to the peak flow discharge. Assuming that the basal pore fluid pressure $\left(p_{\text {bed }}\right)$ was the same as the horizontal water pressure of almost the same height with a depth of grain-fluid flow $(h)$. The general soil property values of solid density $\left(\rho_{s}\right)$, fluid water density $\left(\rho_{f}\right)$, the ratio of solid volume $\left(v_{s}\right)$, and the ratio of fluid volume $\left(v_{f}\right)$ were used for analysis.

The simulation model was created from a three-dimensional terrain model by SfM of aerial photos taken by the UAV and ALOS Global Digital Surface Model, ALOS World 3D 30 m (AW3D30) (Japan Aerospace Exploration Agency Earth Observation Research Center 2020) in Fig. 15. The position of the failure surface is determined based on the position of the slope surface before and after collapse. Figure $15 \mathrm{a}-\mathrm{c}$ show the contour of slope surface before and after collapse which were determined from UAV photos and AW3D30. The three dimensional surface of the slope before and after collapse were simulated by GIS in Fig. 15d, e. The cross-section of the slope surface before and after collapse were determined in Fig. 16 from three dimensional surface. The failure surface was determined based on knowledge from the field survey and the conservation of volume before and after collapse (red line in Fig. 16).

The collapse process was simulated in which the limestone block at the upper part of a waterfall and the talus deposit at the bottom of the slope moved together. The moving mass crossed the river and moved about $400 \mathrm{~m}$ (Fig. 16).

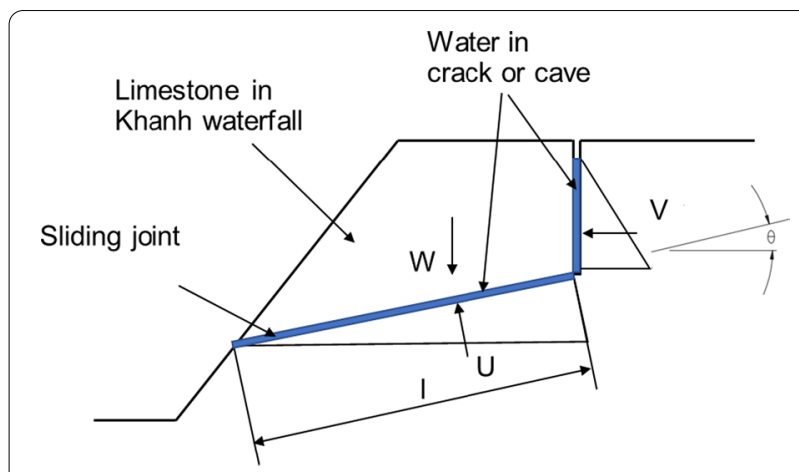

Fig. 13 Slope stability analysis of rock slope (modified from Hoek and Bray 1974)

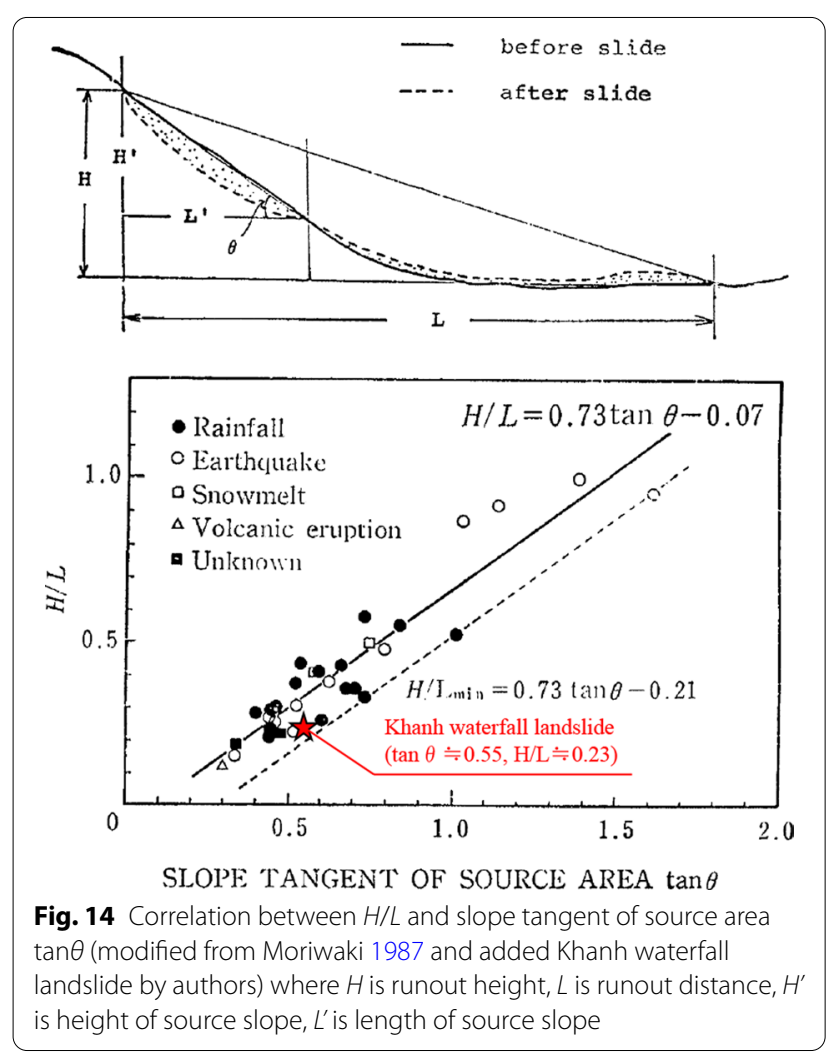

\section{Results of analysis \\ Geology and water quality analysis results}

The geology of the area consists mainly of Triassic shale and limestone of the Mesozoic. The strike of the geological layer is $\mathrm{N} 40-50^{\circ} \mathrm{W}$, and the dip is $70-80^{\circ} \mathrm{W}$. The Khanh-waterfall section is a small fault that is inclined $45^{\circ} \mathrm{E}$. The course of the Kem River along the strike direction of the geological layer might correspond to that fault. The limestone is mainly distributed on the right riverbank in the steep terrain, while the shale is mainly 
Table 1 Physical properties of the flow simulation

\begin{tabular}{|c|c|c|c|}
\hline Parameter & & Value & Unit \\
\hline Time step & $\Delta t$ & 0.005 & $\mathrm{~S}$ \\
\hline Mesh size & $\Delta x \times \Delta y$ & $5 \times 5$ & $\mathrm{~m}$ \\
\hline Internal friction angle before collapse (calculated in Table 2) & $\varphi_{\text {int }}$ & 30 & $\circ$ \\
\hline $\begin{array}{l}\text { Basal friction angle after collapse } \\
\text { (calculated in Table 2) }\end{array}$ & $\varphi_{\text {bed }}$ & 15 & $\circ$ \\
\hline Ratio of basal pore fluid pressure (calculated in Table 3 ) & $\lambda$ & 0.5 & - \\
\hline Gravity acceleration & $g_{z}$ & 9.8 & $\mathrm{~m} / \mathrm{s}^{2}$ \\
\hline
\end{tabular}

distributed on the left bank. The difference between these terrains is likely due to the difference between the weathering resistance characteristics of the distributed geology.

Figure 17 shows the side view and photos at different points along line A-A'. At the top of Khanh waterfall, the limestone layer had many cracks and creeping toward (Fig. 17A). At the middle of the slope, the sliding surface was found at the fault between the limestone layer and the shale layer (Fig. 17B). Limestone containing stalactite that formed the waterfall collapsed along the boundary with the shale, slipped together with the talus deposit at the bottom of the slope, and moved across the river to the opposite hill. Along the line $\mathrm{A}-\mathrm{A}^{\prime}$ along the landslide moving direction, many limestones were found at the toe of the slope and at the opposite hill (Fig. 17C, D). From the field survey at the site, the geological cross-section of Khanh waterfall slope was drawn in Fig. 18.

Downstream of Kem river, the geological cross-section of P1 and P2 areas were drawn in Fig. 19. Both points P1 and P2 had a concave topography which was divided by the ridgeline into the northeast-southwest direction. They show a terraced topography with steps of various heights of $2 \mathrm{~m}$ to $5 \mathrm{~m}$ at the Kem River direction below the slope (Fig. 20a). A lot of spring water was observed in the whole area (Fig. 20b). A shale with a thickness of $30 \mathrm{~cm}$ to $2 \mathrm{~m}$ was projected on the slope at a nearly vertical angle in a plate shape and parallel to the slope (Fig. 20c).

The protruding plate-shaped shale is arranged parallel on the strike of the stratum, and the geology surrounding the shale is limestone. The shale layer sandwiched between the limestone layers can be seen in the karst topography left behind by the differential erosion. There was a small-scale collapse topography with a width of $20 \mathrm{~m}$ to $30 \mathrm{~m}$ that occurred recently at the end of the slope of area P1 (Fig. 20d). However, a main scarp in the entire area P1 and P2 was not recognized.

The water samples filtered through the $0.45 \mu \mathrm{m}$ membrane filter were taken in a polyethylene container for analysis of major ions and dissolved silicic acid. Cations $\left(\mathrm{Na}^{+}, \mathrm{K}^{+}, \mathrm{Ca}^{2+}, \mathrm{Mg}^{2+}\right)$ were analyzed by atomic absorption spectroscopy. Anions $\left(\mathrm{Cl}^{-}, \mathrm{NO}_{3}{ }^{-}, \mathrm{SO}_{4}{ }^{2-}\right)$ were analyzed by ion chromatography. The alkalinity (corresponding to $\mathrm{HCO}_{3}{ }^{-}$concentration) was determined by acid titration using the Gran method (Gran 1952). Then, the dissolved silicic acid (silica $\mathrm{SiO}_{2}$ ) was analyzed by the molybdenum yellow absorption spectrophotometry. The result of water quality analysis are listed in Table 4.

The water quality analysis results were organized as a stiff diagram (Fig. 21). G005, G008 collected from spring water has less silica and more calcium ions than G010, G011, G012. It is highly possible that it was cultivated in limestone. Silica-rich G010, G011, and G012 are greatly affected by weathering of non-limestone as well as limestone (Fig. 22). These differences are consistent with the different collection basins at Khanh waterfall landslide and areas P1 and P2. The surface and groundwater in areas P1 and P2 and the Khanh waterfall landslide area were considered to have different water supply channels due to differences in water quality.

\section{Rainfall and flow discharge calculation results}

The characteristics of the upper stream network channel of Khanh waterfall are listed in Table 5. From these characteristics, the peak flow discharge and the allowable flow discharge were calculated. Using the discharge coefficient $\mathrm{f}$ is 0.7 which is general value in mountains, peak hour rainfall data in Fig. 11 is $44.1 \mathrm{~mm} / \mathrm{h}$ on October 11, 2017, watershed around Khanh waterfall in Fig. 12 is $21.17 \mathrm{~km}^{2}$, the peak flow $Q$ is calculated from Eq. (1).

$$
Q=\frac{1}{3.6} . f . r . A=\frac{1}{3.6} \times 0.7 \times 44.1 \times 21.17=181.5\left(\mathrm{~m}^{3} / \mathrm{s}\right)
$$

From the above calculation results, the amount of water collected around the waterfall during the peak rainfall on October 11 is about $181.5 \mathrm{~m}^{3} / \mathrm{s}$. While the allowable flow is about $3.55 \mathrm{~m}^{3} / \mathrm{s}$, which is about 51 times smaller than peak flow. That causes the water to overflow at Khanh waterfall. This is consistent with the situation around the waterfall before the landslide in Fig. $6 \mathrm{~b}$. 
Table 2 Calculation of correlation between $\mathrm{H} / \mathrm{L}$ and slope tangent of source area $(\tan \theta)$ in the case of Khanh waterfall landslide as shown in Fig. 14

\begin{tabular}{llll}
\hline Characteristics of slope & & After collapse & Before collapse \\
\hline Runout distance after collapse (before collapse) & $\mathrm{L}\left(\mathrm{L}^{\prime}\right)(\mathrm{m})$ & 520 & 220 \\
Runout height after collapse (before collapse) & $\mathrm{H}\left(\mathrm{H}^{\prime}\right)(\mathrm{m})$ & 120 & 120 \\
Correlation between $H / L\left(H^{\prime} / L^{\prime}\right)$ & $H / L\left(H^{\prime} / L^{\prime}\right)$ & 0.23 & 0.55 \\
Slope tangent of source area & $\theta\left(^{\circ}\right)$ & 13 & 29 \\
Rounding up slope tangent of source area (friction angle) & Rounding up $\theta$ (degrees) & 15 & 30 \\
Tangent of rounding up slope tangent of source area & $\theta$ & 0.27 & 0.58 \\
\hline
\end{tabular}

\section{Slope stability analysis and numerical simulation result}

From the geological survey results in "Geology and water quality analysis results" section, there were many cracks and caves in the limestone layer at Khanh waterfall. Torrent rainfall that caused water overflow at Khanh waterfall was analyzed in "Rainfall and flow discharge calculation results" section. The water level in cracks and caves increased the horizontal water pressure and uplift water pressure. According to the Eq. (2), the increasing of horizontal water pressure and uplift water pressure reduced the factor of safety of the slope.

The numerical simulation result of Khanh waterfall landslide is presented in Fig. 23. The simulation result is shown with a 5-s from the initial condition $(t=0 \mathrm{~s})$ to the end of moving $(t=30 \mathrm{~s})$. The red line is a boundary of the mass moving area estimated based on the information provided by local residents and by UAV photo. The horizontal force was increased and failure started from the upper part of the slope at points $\mathrm{A}$ and $\mathrm{B}$. The talus deposit part at point $C$ moved together with the limestone from points $A$ and $B$ to points $D$ and A'. After $15 \mathrm{~s}$, the moving mass crossed the river and the opposite hill at point D. Finally, after $30 \mathrm{~s}$, the mass was deposited at point $\mathrm{A}^{\prime}$ behind the hill. However, most of the moving mass was deposited in front of the hill. Based on the boundary of mass moving area estimated by the information of local residents and by UAV photo, the simulation result is similar to the actual phenomena.

\section{Discussion}

The rainfall data in Fig. 9b suggests that the global weather patterns have been rapidly changing in recent decades. One of such changes is an extremely large amount of rainfall in a short period of time that causes landslides. This trend appears to be a global issue being triggered by climate change. In October 2017, the recored rainfall was $448.8 \mathrm{~mm}$. This rainfall intensity was more than two times higher than the average annual rainfall in
October, and higher than the 58-year average maximum monthly rainfall in August with a rainfall intensity of $344.3 \mathrm{~mm}$ (Fig. 10). The rain was concentrated on October 10 and October 11, 2017 with a rainfall intensity of $394.8 \mathrm{~mm}$ in $48 \mathrm{~h}$, just before the landslide at 1:00 am on October 12, 2017 (Fig. 3). The torrent rainfall flowed into the upper stream network channel and concentrated on Khanh waterfall (Fig. 12). The extremely large amount of water exceeded 51 times of the drainage capacity of the upper stream network channel (Table 5), causing a massive overflow on the top of Khanh waterfall (Fig. 6b).

Overflow water on the top of Khanh waterfall flowed into the cracks and underground caves of the limestone layer (Fig. 17A, B). The water in cracks and underground caves increased the uplift water force and driving water force (Fig. 13). The increasing of destabilizing forces caused the slope to fail. The collapsed surface was the fault between the limestone layer and the shale layer (Fig. 18). The limestone blocks at the top of slope moved together with the talus deposit at the toe of slope. This mixture crossed the river and passed over the opposite hill. The large and fast moving mass destroyed five houses and killed eighteen people at the opposite hill. The collapse process was simulated based on Coulomb mixture theory (Denlinger and Iverson 2001). This method assumes that grain-fluid flows behave as mixtures limestone layer at the top and the talus deposit at the toe of slope. The simulation results show that the range of moving mass is similar to the actual phenomena at Khanh waterfall landslide.

Some previous research on landslides in waterfall areas indicated that they are often caused by the erosion at the toe of the slope (Hayakawa and Matsukura 2010; Hayakawa 2013; Scheingross and Lamb 2017). The collapse of Khanh waterfall was different to this phenomena. Khanh waterfall collapsed due to effects of cracks and caves in the limestone layer of the slope. A large amount of water from stream flowed into cracks and caves in limestone caves. The water in cracks and 
Table 3 Calculation the ratio of basal pore fluid pressure

\begin{tabular}{lllc}
\hline & Density $\mathbf{\rho ~} \mathbf{~ k g} / \mathbf{m}^{\mathbf{3}}$ & Ratio of volume $\mathbf{v}$ & Weight $\mathbf{~ k g}(\boldsymbol{\rho} . \mathbf{v})$ \\
\hline Solid & $2600^{*}$ & 0.6 & 1560.0 \\
Water & 1000 & 0.4 & 400.0 \\
Air & 1 & 0.0 & 0.0 \\
Total weight of landslide mass & & 1960 \\
Ratio of basal pore fluid pressure $(\lambda)=$ Water weight/Total weight & & 0.5
\end{tabular}

* The density of solid was referred from Konecny et al. (2017)
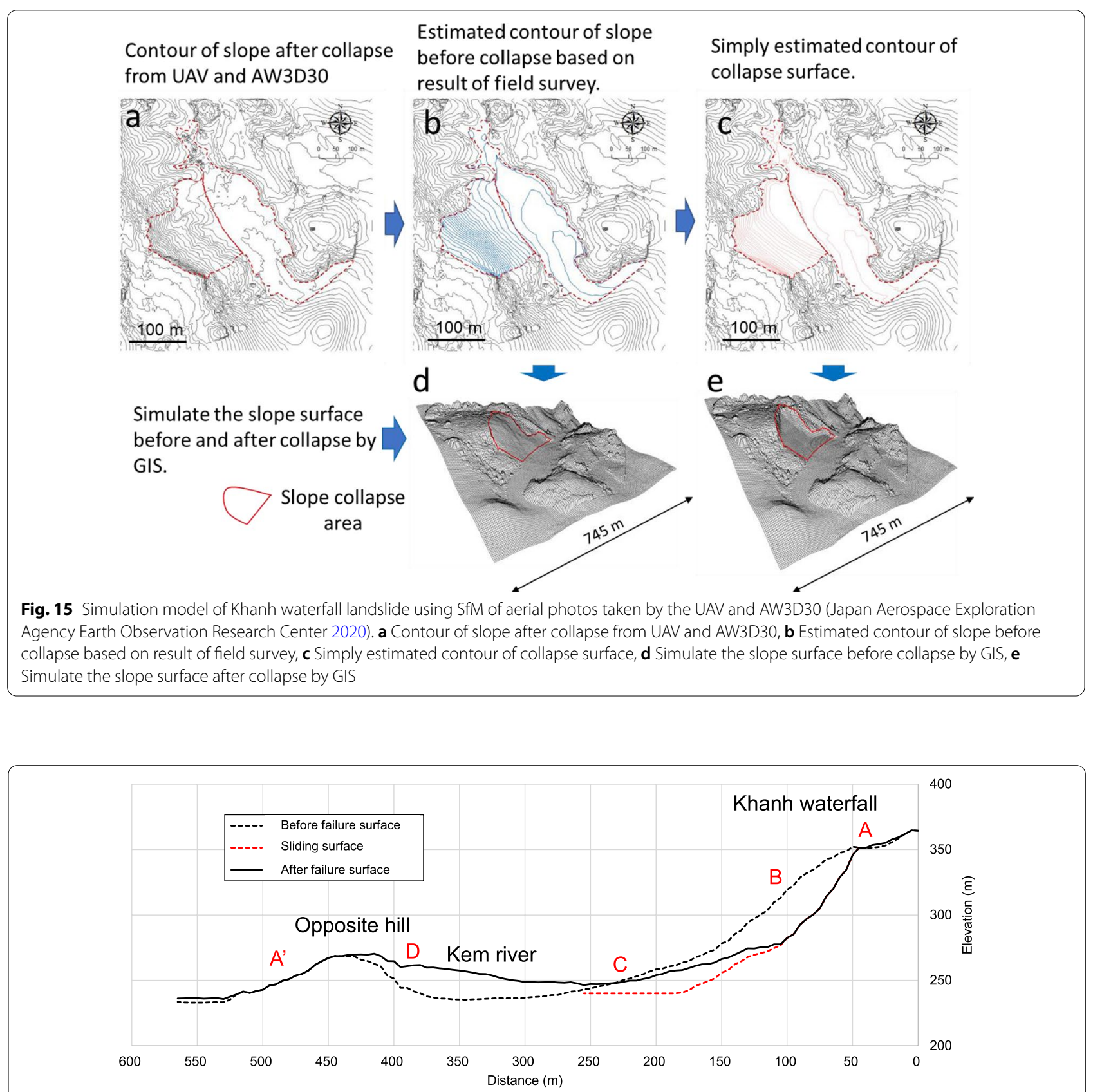

Fig. 16 Cross-section of slope surface before and after failure 


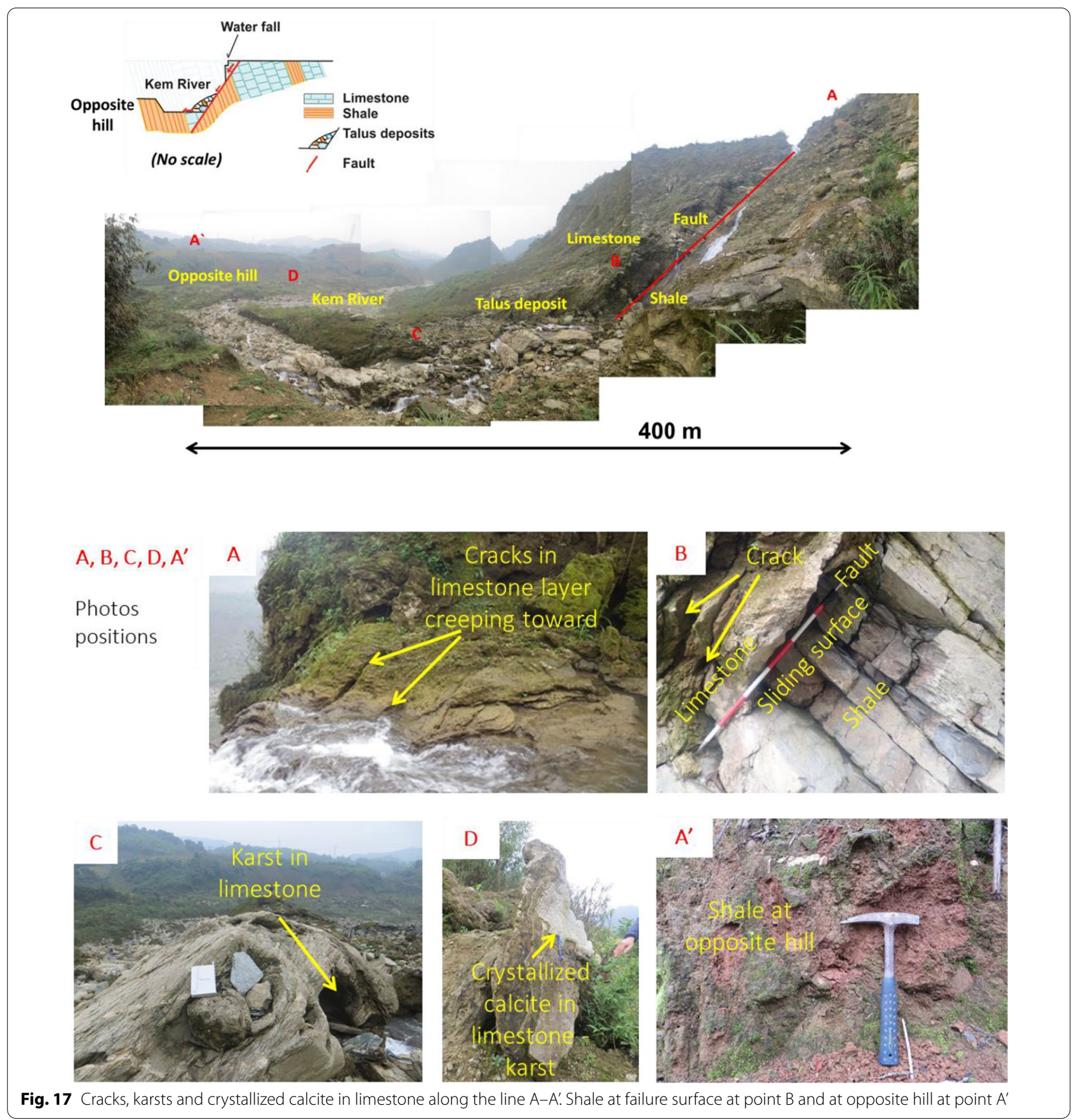

caves increased the uplift water force and driving force causing slope failure.

Regarding the possibility of similar landslides around Khanh waterfall in the future, it is necessary to have a further investigation and assessment of the current underground karsts around Khanh waterfall. Especially a remaining part of Khanh waterfall, Khanh waterfall 2 in Fig. 4, has a similar geology and same water supply channels. There is a high possibility that Khanh 2 waterfall will collapse similar to the phenomena that occured at Khanh waterfall 1.

Another nearby areas are P1 and P2 areas on the right bank downstream of Khanh waterfall. Since the topography of the P1 and P2 areas is similar to the old landslide site, it was feared that landslides would continue to occur in the future. However, the survey results show that the geology at areas P1 and P2 is different from the geology at Khanh waterfall (Fig. 19). The geology at areas P1 and 


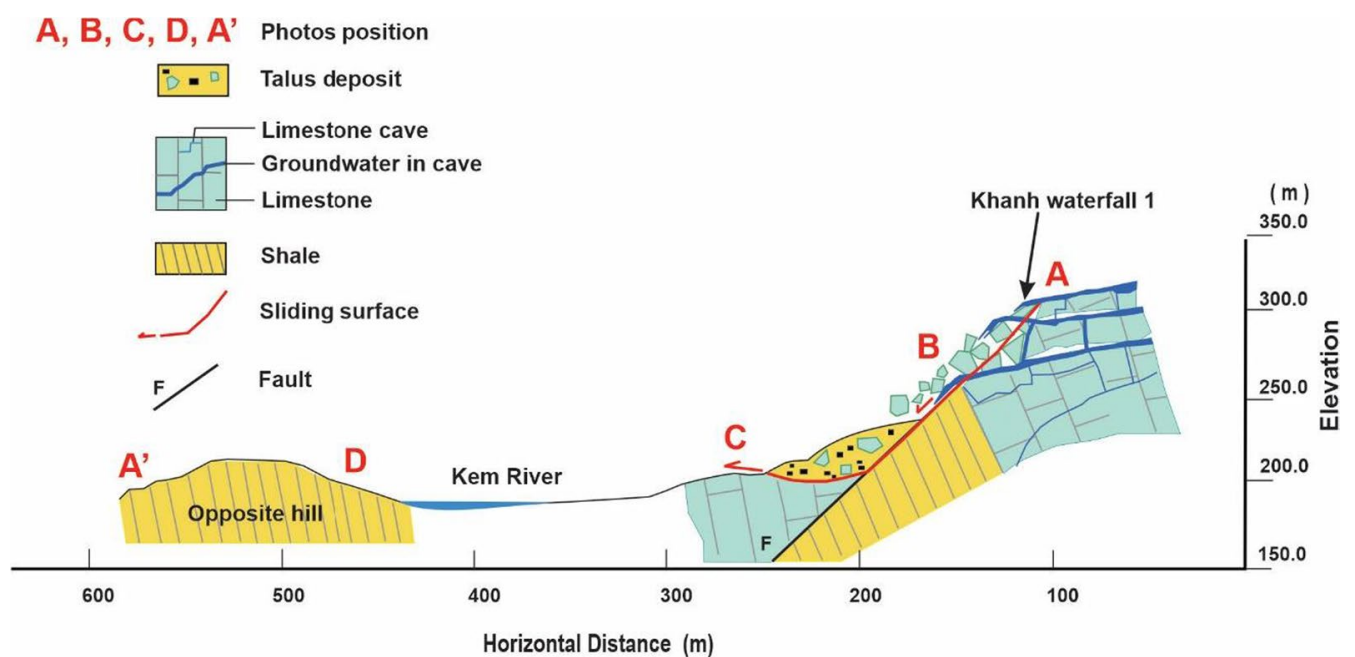

Fig. 18 Geology along line A-A' (center line A-A'in Fig. 5) of Khanh waterfall landslide_-Outcrop of shale and limestone at the right bank of the Kem River after collapse

P2 is mainly limestone interspersed with a thin shale layer. In addition, the surface and groundwater in areas P1 and P2 and the Khanh waterfall landslide area are considered to have different water supply channels due to differences in water quality. It suggests that areas P1 and P2 may have a different phenomena compared with Khanh waterfall landslide.

\section{Conclusion}

In this study, we investigated the mechanism of a landslide occurrence by focusing on the topographical and geological background, the relationship between rainfall and water flow conditions that caused the Khanh waterfall landslide, and the flow mechanism of the moving mass. Furthermore, the possibility of recurrence of such landslide damage was analyzed. The conclusions of this study can be summarized as follows:

1. The collapse of Khanh waterfall was different from some previous collapses of waterfalls due to erosion at the toe of the slope. Due to the torrent rain continuing for $48 \mathrm{~h}$, a large amount of water flowing from the upper stream network channel concentrated in the Khanh waterfall area. It resulted in a large amount of groundwater flowed in the cracks and karsts in Khanh waterfall slope. The water in cracks and karsts increased the uplift water force and driving force causing slope failure. The increasing of destabilizing forces caused the slope to collapse. The sliding surface was the small fault between the limestone layer and the shale layer.

2. The collapse process was simulated based on Coulomb mixture theory. This method assumes that grain-fluid flows behave as mixtures limestone layer and the talus deposit. The simulation results proved the landslide process from collapse to flow that we inferred.

3. Due to the wide distribution of limestone, and the development of karsts in it in many parts of the world, further studies on the development of karsts in waterfall areas are needed to avoid similar disasters as in Khanh waterfall.

4. This research did not focus on the climatological reasons of an abnormal torrent rain leading to the Khanh waterfall disaster. However, the data presented in this research show that it could be a recent pattern caused by the climate change and having global implications.

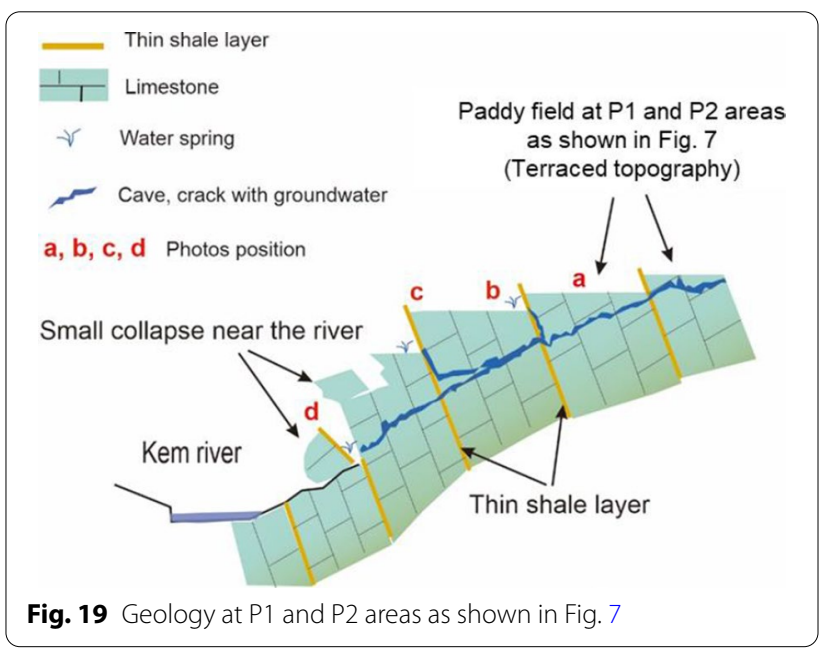




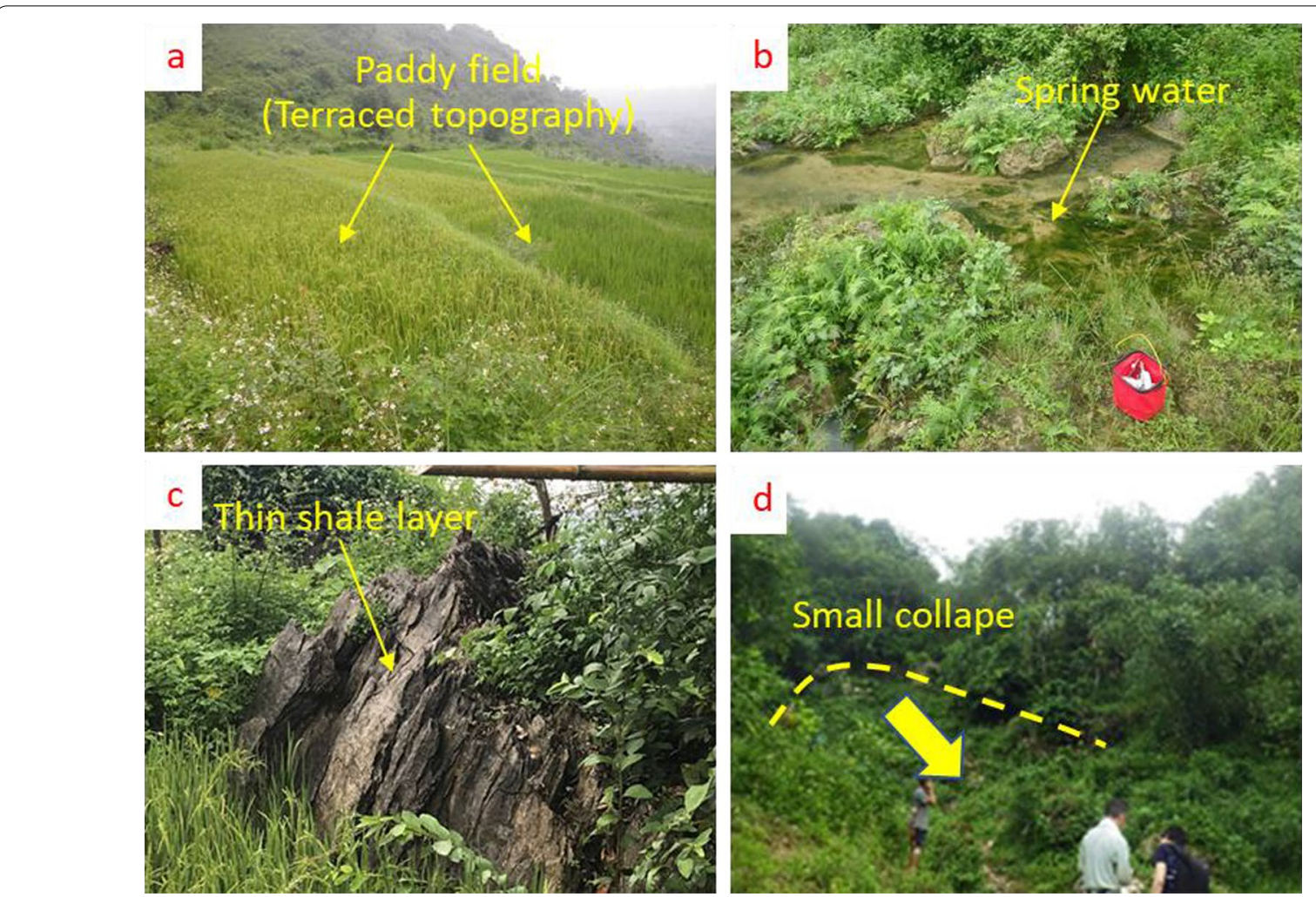

Fig. 20 Photos of a, b, c, d position in Fig. 18, a: terraced topography, b: spring water, c: thin shale layer, d: small collapse area near the river
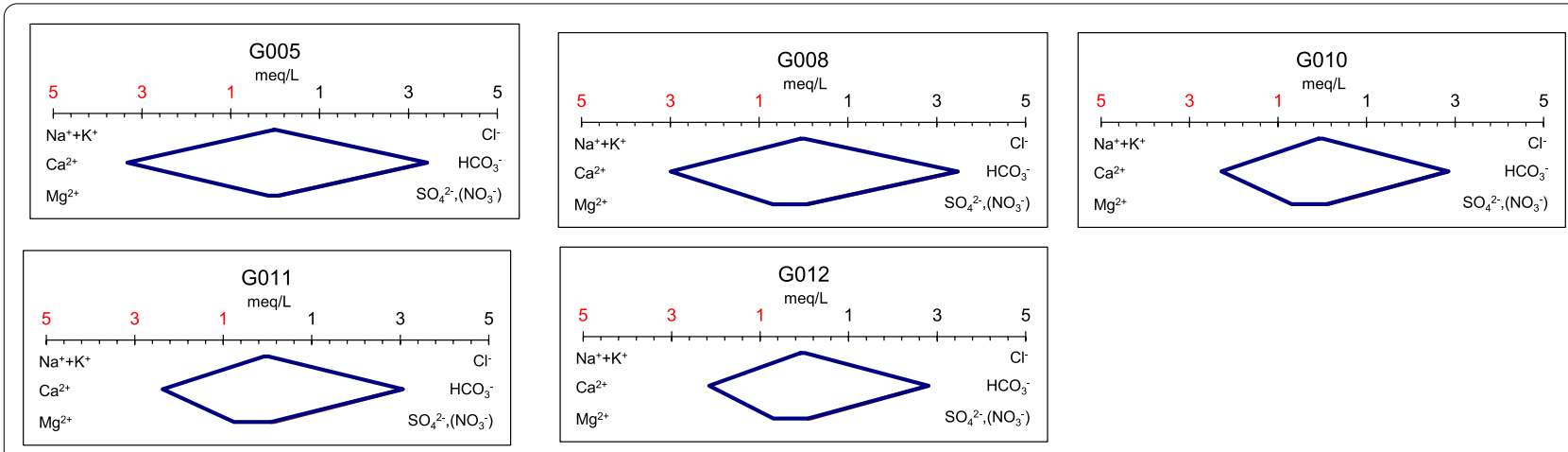

Fig. 21 Stiff diagrams

Table 4 The results of the water quality analysis

\begin{tabular}{|c|c|c|c|c|c|c|c|c|c|c|c|c|c|}
\hline Measurement point & Measuring date & $\begin{array}{l}\mathrm{T} \\
{\left[{ }^{\circ} \mathrm{C}\right]}\end{array}$ & $\begin{array}{l}\mathrm{EC} \\
{[\mathrm{mS} / \mathrm{m}]}\end{array}$ & $\mathrm{pH}$ & $\begin{array}{l}\mathrm{Na}^{+} \\
{[\mathrm{mg} / \mathrm{L}]}\end{array}$ & $\begin{array}{l}\mathrm{K}^{+} \\
{[\mathrm{mg} / \mathrm{L}]}\end{array}$ & $\begin{array}{l}\mathrm{Ca}^{2+} \\
{[\mathrm{mg} / \mathrm{L}]}\end{array}$ & $\begin{array}{l}\mathrm{Mg}^{2+} \\
{[\mathrm{mg} / \mathrm{L}]}\end{array}$ & $\begin{array}{l}\text { alk } \\
\text { [meq/L] }\end{array}$ & $\begin{array}{l}\mathrm{Cl}^{-} \\
{[\mathrm{mg} / \mathrm{L}]}\end{array}$ & $\begin{array}{l}\mathrm{NO}_{3}^{-} \\
{[\mathrm{mg} / \mathrm{L}]}\end{array}$ & $\begin{array}{l}\mathrm{SO}_{4}{ }^{2-} \\
{[\mathrm{mg} / \mathrm{L}]}\end{array}$ & $\begin{array}{l}\mathrm{SiO}_{2} \\
{[\mathrm{mg} / \mathrm{L}]}\end{array}$ \\
\hline G005 Spring water & 2019/9/10 11:33 & 25.8 & 33 & 7.50 & 0.8 & 0.1 & 66.8 & 1.98 & 3.42 & 0.3 & 0.7 & 3.6 & 7.3 \\
\hline G008 Spring water & 2019/9/10 13:16 & 26.0 & 35 & 7.31 & 1.1 & 0.8 & 60.0 & 8.34 & 3.47 & 0.7 & 0.7 & 3.3 & 7.4 \\
\hline G010 Surface water & 2019/9/10 14:04 & 25.5 & 28 & 8.03 & 1.3 & 1.1 & 45.6 & 8.43 & 2.85 & 0.5 & 2.2 & 4.9 & 10.5 \\
\hline G011 Spring water & 2019/9/10 14:18 & 25.9 & 30 & 8.12 & 1.2 & 1.1 & 47.4 & 9.29 & 3.06 & 0.7 & 4.8 & 4.0 & 9.9 \\
\hline G012 Surface water & 2019/9/10 14:33 & 25.5 & 28 & 8.09 & 1.3 & 1.0 & 43.0 & 8.53 & 2.8 & 0.4 & 3.4 & 3.9 & 10.8 \\
\hline
\end{tabular}



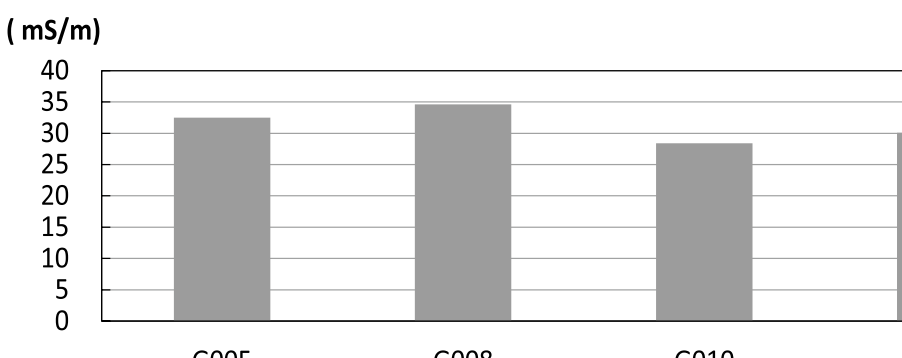

G010

G011

$\mathrm{SiO}_{2}$

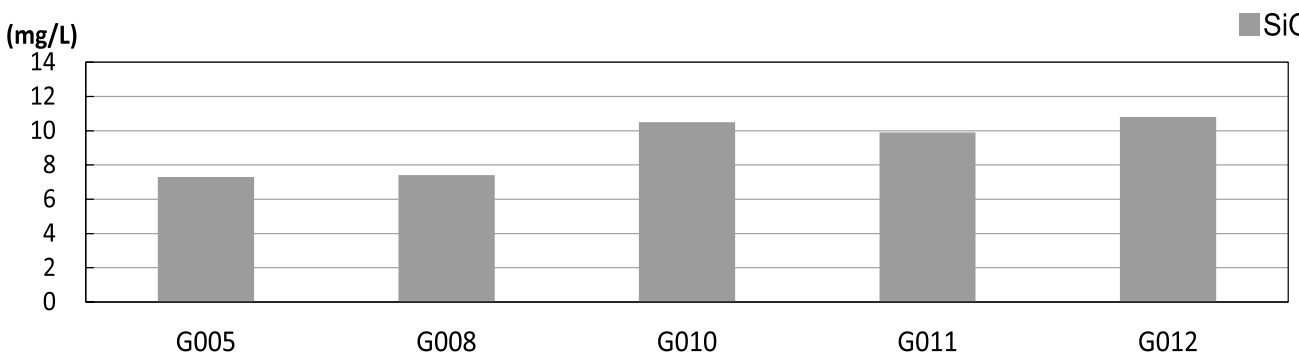

Fig. 22 Electrical conductivity $(\mathrm{EC})$ and silica concentration $\left(\mathrm{SiO}_{2}\right)$

Table 5 The characteristics of the upper stream network channel of Khanh waterfall

\begin{tabular}{|c|c|c|c|}
\hline Basic characteristics & Unit & Value & Calculated equation \\
\hline Width of channel (B) & $\mathrm{m}$ & 3.00 & \\
\hline \multirow[t]{2}{*}{ Height of channel $(H)$} & $\mathrm{m}$ & 2.00 & \\
\hline & & & \\
\hline Left slope of channel (1:m1) & & 0.50 & \\
\hline Right slope of channel (1:m2) & & 0.50 & \\
\hline Roughness coefficient (n) & & 0.10 & \\
\hline Slope gradient (I) & $\%$ & 0.18 & \\
\hline Peak flow (Q) & $\mathrm{m}^{3} / \mathrm{s}$ & 181.5 & \\
\hline a & & 0.80 & \\
\hline Cross-sectional area $(\mathrm{A})$ & $m^{2}$ & 8.00 & $A=H\{2 B+(m 1+m 2) H\} / 2$ \\
\hline Wetted perimeter $(\mathrm{P})$ & $\mathrm{m}$ & 7.47 & $P=B+H\left\{\left(1+m 1^{2}\right)^{1 / 2}+\left(1+m 2^{2}\right)^{1 / 2}\right\}$ \\
\hline Hydraulic radius ( $\mathrm{R}$ ) & $\mathrm{m}$ & 1.07 & $\mathrm{R}=\mathrm{A} / \mathrm{P}$ \\
\hline Allowable flow (Qmax) & $\mathrm{m}^{3} / \mathrm{s}$ & 3.55 & Qmax $=I^{1 / 2} \cdot R^{2 / 3} \cdot A / n$ \\
\hline Peak flow/allowable flow & & 51 & Q/ Qmax \\
\hline
\end{tabular}



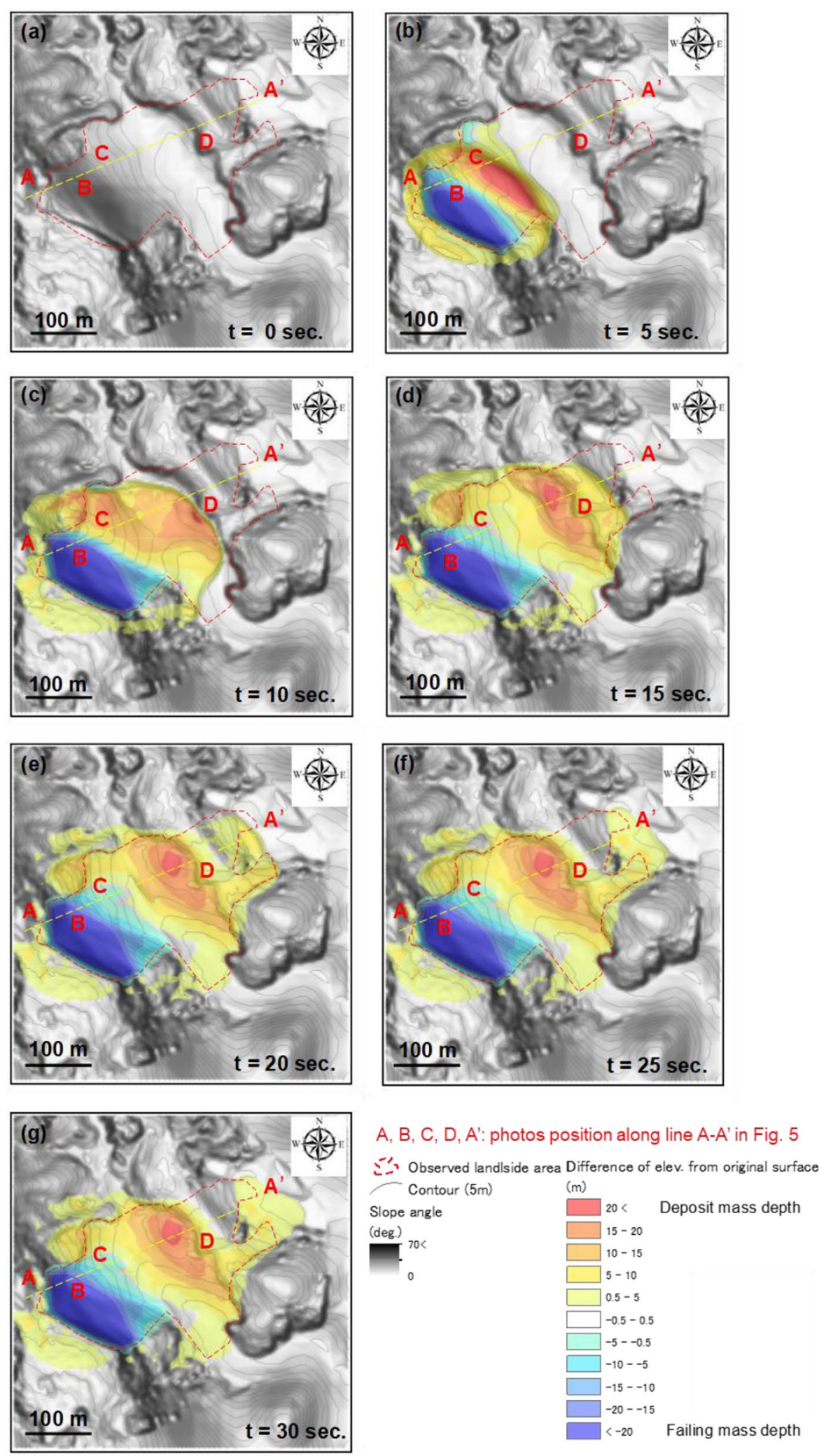

Fig. 23 Simulation result of Khanh waterfall landslide with a 5-s interval from initial condition to the end of moving: $\mathbf{a}$ at initial condition, $\mathbf{b}$ at $5 \mathrm{~s}, \mathbf{c}$ at $10 \mathrm{~s}, \mathbf{d}$ at $15 \mathrm{~s}, \mathbf{e}$ at $20 \mathrm{~s}, \mathbf{f}$ at $25 \mathrm{~s}, \mathbf{g}$ at the end $30 \mathrm{~s}$ 


\section{Acknowledgements}

Authors are grateful to Mr. Satoshi Suzuki of Okuyama Boring Co., Ltd, Japan, Mr. Doan Huy Loi, Mr. Le Hong Luong, Mr. Huynh Thanh Binh, and Mr. Phan Van Chuong of Institute of Transport Science and Technology, Vietnam, and Mr. Tran Song Manh for their support during this study.

\section{Authors' contributions}

$\mathrm{NHD}, \mathrm{SG}, \mathrm{SA}, \mathrm{KTN}, \mathrm{KH}$ and $\mathrm{OW}$ visited the landslide site and conducted the field survey. NHD, SA and SG contributed to geology survey and slope stability analysis. KTN, TM and KH contributed to mapping. OW, NHD, SG and SA contributed to water quality analysis, rainfall and flow discharge calculation. $\mathrm{KH}$ and SA contributed to numerical simulation of collapse process. NHD, SG and SA wrote the manuscript, edited and finalized the corrections. All authors read and approved the final manuscript.

\section{Funding}

The authors received no specific funding for this research work.

\section{Availability of data and materials}

All data and materials are available from the corresponding author upon reasonable request.

\section{Declaration}

\section{Competing interests}

The authors declare that they have no competing interests.

\section{Author details}

${ }^{1}$ Civil Management and Engineering Major, Environmental and Social System Science Course, Integrated Graduate School of Medicine, Engineering, and Agricultural Sciences, University of Yamanashi, Yamanashi, Japan. ${ }^{2}$ Faculty of Engineering, Graduate Faculty of Interdisciplinary Research, University of Yamanashi, Yamanashi, Japan. ${ }^{3}$ Okuyama Boring Co., Ltd, Akita, Japan. ${ }^{4}$ Institute of Transport Science and Technology, Hanoi, Vietnam. ${ }^{5}$ Advantechnology Co., Ltd, Miyagi, Japan. ${ }^{6}$ Suimonkikaku LLC, Miyagi, Japan.

Received: 28 August 2021 Accepted: 24 January 2022

Published online: 21 February 2022

\section{References}

Bui DT, Pradhan B, Lofman O, Revhaug I, Dick OB (2013) Regional prediction of landslide hazard using probability analysis of intense rainfall in the Hoa Binh province. Vietnam Nat Hazards 66:707-730. https://doi.org/10.1007/ s11069-012-0510-0

Bui DT, Tuan TA, Hoang ND, Thanh NQ, Nguyen DB, Liem NV, Pradhan B (2017) Spatial prediction of rainfall-induced landslides for the Lao Cai area (Vietnam) using a hybrid intelligent approach of least squares support vector machines inference model and artificial bee colony optimization. Landslides 14:447-458. https://doi.org/10.1007/s10346-016-0711-9

Denlinger RP, Iverson RM (2001) Flow of variably fluidized granular masses across three-dimensional terrain. 2. Numerical predictions and experimental tests. J Geophys Res 106(B1), 553-566

Department of Geology and Minerals of Viet Nam (2004) Geological and mineral resources map of Viet Nam on 1:200.000 Ninh Binh F-48-XXXIV

Department of Geology and Minerals of Viet Nam (2005) Geological and mineral resources map of Viet Nam on 1:200.000 Ha Noi F-48-XXVII

Duc DM (2013) Rainfall-triggered large landslides on 15 December 2005 in Van Canh District, Binh Dinh Province, Vietnam". Landslides 10:219-230. https://doi.org/10.1007/s10346-012-0362-4

Gran G (1952) Determination of the equivalence points in potentiometric titrations-part II. Analyst 77:661-671

Hau VT, Kim Y, Ngo T, Tran HT, Yi K (2018) Neoproterozoic deposition and Triassic metamorphism of metasedimentary rocks in the Nam Co Complex, Song Ma Suture Zone. NW Vietnam Geosci J 22(4):549-568

Hayakawa YS (2013) Stability analysis of cliff face around Kegon Falls in Nikko, Eastern Japan: an implication to its erosional mechanisms. Int J Geosci 4:8-16
Hayakawa YS, Matsukura Y (2010) Stability analysis of waterfall cliff face at Niagara Falls: an implication to erosional mechanism of waterfall. Eng Geol 116:178-183

Hicks B, Gray S, Ball JE (2009) A critical review of the urban rational method. In: Proceedings of H2009, 32nd hydrology and water resources symposium, engineers Australia, ISBN 978-08258259461

Hoek E, Bray J (1974) Rock slope engineering. Institution of Mining and Metallurgy, London

Japan Aerospace Exploration Agency Earth Observation Research Center (2020) ALOS Global Digital Surface Model "ALOS World 3D - 30m (AW3D30)". https://www.eorc.jaxa.jp/ALOS/en/aw3d30/index.htm/. Accessed July 2020

Khang P (1985) The development of karst landscapes in Vietnam. Acta Geol Pol 35(3-4):305-319

Konecny P, Hagi A, Plevova E, Vaculikova L, Murzyn T (2017) Characterization of Limestone from Cement Plant at Berbera (Republic of Somaliland). Procedia Eng 191:43-50

Loi DH, Quang LH, Sassa K, Takara K, Dang K, Thanh NK, Tien PV (2017) The 28 July 2015 rapid landslide at Ha Long City, Quang Ninh. Vietnam Landslides 14:1207-1215. https://doi.org/10.1007/s10346-017-0814-y

Moriwaki H (1987) A prediction of the runout distance of a debris. J Jpn Landslide Soc 24(2):10-16. https://doi.org/10.3313/jls1964.24.2_10 (in Japanese with English abstract)

Nguyen LC, Tien PV, Do TN (2020) Deep-seated rainfall-induced landslides on a new expressway: a case study in Vietnam. Landslides 17:395-407. https:// doi.org/10.1007/s10346-019-01293-6

Quang LH, Loi DH, Sassa K, Takara K, Ochiai H, Dang K, Abe S, Asano S, Ha DN (2018) Susceptibility assessment of the precursor stage of a landslide threatening Haivan Railway Station. Vietnam Landslides 15:309-325. https://doi.org/10.1007/s10346-017-0870-3

Scheidegger AE (1973) On the prediction of the reach and velocity of catastrophic landslides. Rock Mech 5:231-236

Scheingross JS, Lamb MP (2017) A Mechanistic model of waterfall plunge pool erosion into bedrock. J Geophys Res Earth Surf, pp 2079-2104

Tan MT, Liem NV, Tuan DA, Tien NV (2015) Correlation analysis between landslides and rainfall in Mai Chau, Hoa Binh. J Sci Vietnam Natl Univ Hanoi 31(4):51-63 (in Vietnamese)

Tung BD, Luong LH, Cuong PV, Thanh NK, Manh TS, Watanabe O, Fujii N, Abe S (2016) A preliminary study on the mechanism of landslide in limestone formation area in Son La. Northern Viet Nam. In: Proceedings of the 2016 international conference on sustainability in civil engineering, Geotechnical Engineering, pp 76-80

Tuoi Tre Media (2017) Khanh waterfall before and after a serious landslide caused 18 people buried. YouTube https://www.youtube.com/watch? $v=$ B6iU3eYA7_Q. Accessed Dec 2019 (in Vietnamese)

Vietnam Meteorological and Hydrological Administration (2019) Accessed Dec 2019

Vietnamnet (2017) Photos of 200m-waterfall before burying 18 people in Hoa Binh. Vietnamnet https://vietnamnet.vn/vn/thoi-su/moi-truong/lu-lut-ohoa-binh-hinh-anh-thac-nuoc-200-met-truoc-khi-vui-18-nguoi-404815. html. Accessed Dec 2019 (in Vietnamese)

Zhang C, Yoshimatsu H, Iwahori Y, Abe S (2004) Numerical simulation of grainfluid flow due to slope collapse. J Jpn Landslide Soc 41(1), pp 9-17 (in Japanese with English abstract) https://doi.org/10.3313/jls.41.9

\section{Publisher's Note}

Springer Nature remains neutral with regard to jurisdictional claims in published maps and institutional affiliations. 